\title{
65 YEARS OF THE DOUBLE HELIX Endocrine tumour syndromes in children and adolescents
}

\author{
Catherine Goudie', Fady Hannah-Shmouni², Mahmure Kavak ${ }^{3}$, Constantine A Stratakis ${ }^{2}$ and William D Foulkes ${ }^{4}$ \\ 'Division of Hematology-Oncology, Department of Pediatrics, The Hospital for Sick Children, Toronto, Canada \\ 2Section on Endocrinology and Genetics, The Eunice Kennedy Shriver Institute of Child Health and Human Development, National Institutes of Health, \\ Bethesda, Maryland, USA \\ ${ }^{3}$ Department of Pharmacology and Toxicology, University of Toronto, Toronto, Canada \\ ${ }^{4}$ Department of Human Genetics, Research Institute of the McGill University Health Centre, and Lady Davis Institute, Jewish General Hospital, McGill \\ University, Montreal, Canada \\ Correspondence should be addressed to W D Foulkes: william.foulkes@mcgill.ca
}

This paper is part of a thematic review section celebrating 65 Years of the Double Helix. The guest editors for this section were Charis Eng, William Foulkes and Jérôme Bertherat. W Foulkes was not involved in the review or editorial process for this paper, on which he is listed as an author.

\begin{abstract}
As medicine is poised to be transformed by incorporating genetic data in its daily practice, it is essential that clinicians familiarise themselves with the information that is now available from more than 50 years of genetic discoveries that continue unabated and increase by the day. Endocrinology has always stood at the forefront of what is called today 'precision medicine': genetic disorders of the pituitary and the adrenal glands were among the first to be molecularly elucidated in the 1980s. The discovery of two endocrine-related genes, GNAS and RET, both identified in the late 1980s, contributed greatly in the understanding of cancer and its progression. The use of RET mutation testing for the management of medullary thyroid cancer was among the first and one of most successful applications of genetics in informing clinical decisions in an individualised manner, in this case by preventing cancer or guiding the choice of tyrosine kinase inhibitors in cancer treatment. New information emerges every day in the genetics or system biology of endocrine disorders. This review goes over most of these discoveries and the known endocrine tumour syndromes. We cover key genetic developments for each disease and provide information that can be used by the clinician in daily practice.
\end{abstract}

\author{
Key Words \\ - endocrine tumour \\ syndromes \\ - genetics \\ - Li-Fraumeni syndrome \\ - MEN1
}

\section{Introduction}

In the last three decades, genetic discoveries through the advances in molecular technology have enabled the identification of many genes that have been linked with the development of paediatric malignancies including endocrine tumours, both at the germline and somatic level (Oberg et al. 2016, Grobner et al. 2018). This has led to significant progress in our understanding of the molecular drivers and potential for novel treatment options for these neoplasms.

Benign and malignant endocrine neoplasms in childhood and adolescence form a widely heterogeneous group of disorders often presenting with subtle clinical or biochemical features that are often missed or misdiagnosed during a clinical encounter. Endocrine tumours 
developing in young patients are quite characteristic for certain cancer predisposition syndromes (CPSs). A wide spectrum of non-malignant and malignant tumours within each syndrome exists, with poor genotype-tophenotype correlation. Thus, experienced clinicians working in established centres of excellence are generally required to care for at risk or affected individuals with these syndromes.

As with many other malignancies, studies of the genomic landscape of endocrine tumours have formed the basis for understanding pathogenesis, clinical behaviour and implementing clinical trials evaluating novel targeted agents. Alterations in the RET gene is a classic example of an early genomic discovery directly impacting thyroid carcinoma diagnosis and management. RET point mutations and rearrangements in thyroid carcinoma have led to a wider therapeutic arsenal with tyrosine kinase inhibition. At a germline level, RET genotype-phenotype correlations have been established in patients with multiple endocrine neoplasia type 2 (MEN2), which impacts our tumour surveillance and prevention strategies. The identification of links between CPS and endocrine neoplasms has also contributed to our knowledge of tumour molecular drivers. The implication of Wnt pathway signalling in papillary thyroid carcinoma (PTC) and its cribriform-morular variant was recognised through the association in patients with familial adenomatous polyposis and thyroid carcinoma.

These examples illustrate only a few of the impacts of genetics in childhood endocrine tumours in this era of molecular genomics. This review focuses on the established and novel germline and somatic features of endocrine tumours in childhood and adolescence, highlighting the influence of genomics in our current understanding of their pathogenesis and clinical behaviour. Each section included in this review is subdivided in the same manner, starting with the neoplasm classification and molecular features, followed by a description of the associated CPS. CPSs are featured in the section where the association is the highest with the tumour type. A timeline featuring the first descriptions of these endocrine tumour-related CPSs and their genetic background is shown in Fig. 1.

\section{Adrenal tumours}

\section{Classification and molecular features}

An adrenal tumour or mass represents an overgrowth of adrenal tissues that arises from within the adrenal cortex or medulla. These tumours can be unilateral or bilateral with a tendency to overproduce hormones. They are broadly classified as adrenocortical adenomas (ACAs), adrenocortical hyperplasia, pheochromocytomas and adrenocortical cancer (ACC) (Stratakis \& Boikos 2007). A careful histologic examination of the adrenal tissue by an experienced pathologist is a critical step in subtyping the various types of adrenal tumours. In a postmortem study of patients over 50 years of age, adrenocortical hyperplasia and ACAs were present in 36\% and 5\% of cases, respectively (Saeger et al. 1998). Conversely, these lesions are extremely rare in childhood and adolescence. Their presence should raise the possibility of an inherited condition. Moreover, ACCs are rare with an incidence of 0.5-2 million per year, affecting females across all ages with higher frequency (ratio of female to male ranges from 1.5 to $2.5: 1$ ) and a median age of diagnosis of $\sim 46$ years. In childhood, ACCs represent as many as $1.3 \%$ of all cancers in children (Icard et al. 2001), with a worldwide incidence of $\sim 0.3$ million per year and higher figures in Southern Brazil (3.4-4.2 million per year) (Custodio et al. 2012).
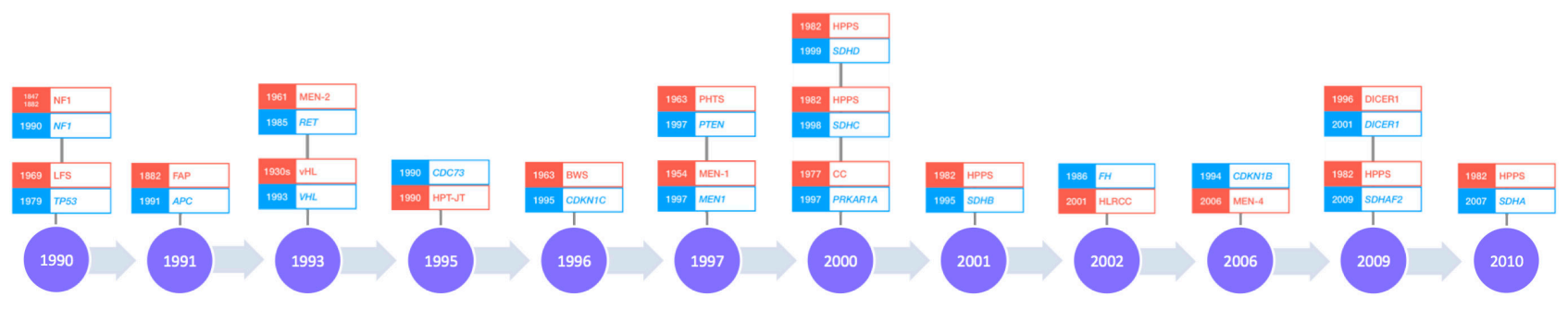

Figure 1

This timeline represents, to the best of our knowledge, the year of the first description of the cancer predisposition syndrome, the year of the discovery of the genes that are implicated with these diseases and the year where the association was made between each gene and disease. In red, year of the first description of the disease; in blue, year of gene discovery; in purple, year in which the association was made between the gene and the disease. BWS, Beckwith-Wiedemann syndrome; CC, Carney complex; DICER1, DICER1 syndrome; FAP, familial adenomatous polyposis; LFS, Li-Fraumeni syndrome; HLRCC, hereditary leiomyomatosis and renal cell carcinoma; HPPS, hereditary pheochromocytoma and paraganglioma syndrome; HPT-JT, hyperparathyroidism-jaw-tumour syndrome; MEN1, multiple endocrine neoplasia type 1; MEN2, multiple endocrine neoplasia type 2; NF1, neurofibromatosis type 1; PHTS, PTEN hamartoma tumour syndrome; MEN4, multiple endocrine neoplasia type 4; vHL, von Hippel-Lindau. 
The advances in genetic technologies and testing have enabled the subclassification of these tumours. This is particularly important for those presenting as hyperplasia or ACC; culprit pathogenic germline variants will help identify the syndrome in question, which in turn affects management and family counselling and testing.

\section{Adrenocortical adenoma}

Approximately $10 \%$ of ACAs are functional and are subdivided into aldosterone-, cortisol- and/or androgenproducing adenomas. ACAs are small (typically less than $5 \mathrm{~cm}$ ), well-circumscribed, solid lesions that appear as bright yellow due to their enriched cytoplasmic lipid. Approximately, $75-90 \%$ of adrenocortical tumours leading to Cushing syndrome are caused by unilateral cortisolproducing adenomas, half of them bearing a somatic mutation in the PRKACA gene (Lodish \& Stratakis 2016).

\section{Adrenocortical hyperplasia}

Adrenocortical hyperplasia are divided into two broad categories - micronodular $(<1 \mathrm{~cm}$ in diameter $)$ or macrocronodular ( $>1 \mathrm{~cm}$ in diameter) (Stratakis \& Boikos 2007). Secondary bilateral adrenocortical hyperplasia with or without autonomous functioning can be observed with ACTH stimulation from either ectopic ACTH secretion or Cushing disease (Stratakis \& Boikos 2007). In micronodular hyperplasia, the presence of pigmentation (i.e. mainly lipofuscin) within the lesion or the surrounding adrenal cortex is characteristic of primary pigmented nodular adrenocortical disease (PPNAD). PPNAD is usually diagnosed in children and young adults, and is either pigmented, as seen in Carney complex (CNC), or isolated (iPPNAD). Isolated micronodular adrenocortical hyperplasia (iMAD) is the other major subtype of micronodular hyperplasia and usually presents in infancy with severe Cushing syndrome. iMAD is histologically characterised by moderate diffuse cortical hyperplasia with multiple small yellow-to-dark brown nodules surrounded by a cortex with a uniform appearance. Mutations in PRKAR1A, PDE11A, PDE8B or germline duplications of PRKACA have been implicated in iMAD. Two important phosphodiesterases, which represent enzymes that hydrolyse cyclic AMP (Francis et al. 2011, Azevedo et al. 2014), have been implicated in micronodular adrenocortical diseases: PDE8B and PDE11A. Genetic polymorphisms in these genes may be low-penetrance alleles that predispose to adrenocortical tumours. PDE8 encodes two highly specific enzymes (PDE8A and PDE8B) responsible for degrading cyclic AMP
(Lakics et al. 2010). The first report of mutations in PDE8B in iMAD was described in a 2-year-old girl who harboured a novel germline missense mutation in PDE8B (c.914A $>$ C, p.P305H) that she inherited from her father (Horvath et al. 2008). This example highlights the progress in molecular diagnostic technology allowing genetic discoveries in rare adrenocortical tumours.

Macronodular hyperplasia is usually diagnosed in adults $>50$ years and can be either sporadic or familial. The most common cause of macronodular hyperplasia is primary bilateral macronodular adrenocortical hyperplasia (PBMAH), which represents a heterogeneous benign disorder responsible for $\sim 10 \%$ and $15 \%$ of Cushing syndrome in young adulthood and childhood, respectively (Stratakis \& Boikos 2007). Various biochemical patterns may be observed, including overt Cushing syndrome, co-secretion of aldosterone and cortisol (or its precursor steroids, and even oestrogens) or aldosterone only (Bourdeau et al. 2007, Hsiao et al. 2009). Cortisol secretion may be mediated by non-mutated aberrant receptors of gastrointestinal peptide, vasopressin, serotonin, catecholamines, luteinising hormone or autocrine/ paracrine ACTH, among other factors (Bourdeau et al. 2001, Lacroix et al. 2010). Pathogenic variants in the tumour suppressor ARMC5 were identified $>50 \%$ of apparent sporadic and familial PBMAH cases, where both alleles carried one germline and one somatic mutation each (Assie et al. 2013, Alencar et al. 2014, Faucz et al. 2014). A second somatic defect, either 16p loss of heterozygosity or a second somatic mutation in the coding region of $A R M C 5$ is required in addition to the germline mutation in AMRC5 to mediate tumourigenesis leading to polyclonal nodularity (Correa et al. 2015). Genetic variance is observed in $A M R C 5$, where the second new ('private') and completely inactivating somatic ARMC5 defect is present in each respective nodule in addition to the germline variant (Correa et al. 2015). PBMAH due to ARMC5 mutations tends to have larger adrenal glands, with increased frequency of nodules and severe hypercortisolaemia (Espiard et al. 2015). Other genetic defects leading to PBMAH include activating mutations of GNAS without features of McCune-Albright syndrome (Fragoso et al. 2003, Hsiao et al. 2009), germline pathogenic variants in PDE11A, FH, MEN1 and APC (Fragoso et al. 2003, Hsiao et al. 2009). Germline duplications of PRKACA resulting in copy number gains have been reported in one family that presented with PBMAH (Beuschlein et al. 2014). Predictive testing of at-risk children and adolescents in a family with PBMAH is an important aspect of genetic testing and counselling. 
From our experience (NICHD, NIH), children harbouring a damaging pathogenic mutation in AMRC5 do not develop adrenocortical hyperplasia in early childhood.

\section{Familial syndromes}

\section{Li-Fraumeni syndrome}

Li-Fraumeni syndrome (LFS) is an autosomal dominant condition due to pathogenic variants in TP53 that predisposes to multiple cancer types (Table 1). The lifetime risk of cancer development is 75\% in men and 93\% in women, with approximately half of patients symptomatic by age 30 years (Sorrell et al. 2013, Testa et al. 2013). Highly penetrant disease with early-onset cancers is seen with mutations in the DNA-binding portion of TP53. ACC in childhood is a characteristic feature of LFS and is 2.7fold more common in girls (Amadou et al. 2018). While $50-80 \%$ of these tumours in children are due to germline TP53 pathogenic variants, only $\sim 10 \%$ of all LFS patients develop ACC at a median age of 3 years (RodriguezGalindo et al. 2005, Gonzalez et al. 2009, Amadou et al. 2018). When compared to somatic TP53-mutant ACCs, their germline counterparts are larger, more aggressive, with greater resistance to chemotherapy/radiation and overall rates of relapse (Sorrell et al. 2013). In Southern Brazil, the prevalence of children with adrenocortical tumours is $\sim 15$-fold higher than in the rest of the world and related to a founder germline TP53 mutation (p.R337H) (Ribeiro et al. 2001, Pinto et al. 2004). The prevalence of this mutation reaches $0.3 \%$ with a penetrance of $\sim 2 \%$ for adrenocortical tumours; newborn screening strategies for the detection of this founder mutation in Southern Brazil have been shown to be advantageous (Custodio et al. 2013). ACCs in childhood should warrant testing for LFS. Along with choroid plexus carcinoma, rhabdomyosarcoma and medulloblastoma, ACCs account for the predominant cancer types seen in children with LFS.

\section{Beckwith-Wiedemann syndrome}

Beckwith-Wiedemann syndrome (BWS) is the prototypical disorder of genetic imprinting with an estimated prevalence of $\sim 1 / 10,000$ (Mussa et al. 2013). Children with BWS are predisposed to developing adrenocortical hyperplasia and lesions, such as adenomas, cysts and ACC (in approximately 1\% of affected children) (Else 2012). Conversely, adults with BWS do not seem to have an increased risk of tumour development. ACC is also seen in idiopathic lateralised overgrowth, which shares features with BWS (Tan \& Amor 2006). BWS affects females and males equally and is caused by alterations in two domains that regulate methylation and maintain a normal balance between maternally expressed growth suppressors and paternally expressed growth promoters. These include regions centre 1 (IC1), which regulates the expression of IGF2 and H19 in domain 1, and imprinting centre 2 (IC2), which regulates the expression of CDKN1C, KCNQ10T1 and KCNQ1 in domain 2 (Shuman et al. 1993). The clinical features of BWS are presented in Table 1. Recently, a comprehensive consensus statement including a scoring system for genetic testing in patients with clinical features of BWS was presented by Brioude et al. (2018).

\section{Carney complex}

The main neuroendocrine manifestation of $\mathrm{CNC}$ is Cushing syndrome from PPNAD, which is biochemically diagnosed in approximately $60 \%$ of patients. PPNAD presents with mild and progressive hypercortisolaemia that is often treated with bilateral adrenalectomy. The prevalence of CNC is unknown, but over 800 cases are known (Stratakis, unpublished data), with a mean age of diagnosis of 20 years. CNC is a rare autosomal dominant hereditary multiple neoplasia syndrome that predisposes to the formation of pigmented skin lesions (lentiginosis and blue nevi) and various endocrine neoplasms including pituitary somatotroph and thyroid tumours (Table 1).

Three distinct loci of $\mathrm{CNC}$ exist without a clear phenotypic difference. CNC type 1 (CNC1) is caused by mutations in PRKAR1A, an apparent tumour suppressor gene, which encodes for the R1a subunit of PKA with an overall penetrance of $>95 \%$ by the age of 50 years (Stratakis et al. 2001). More than $60 \%$ of patients with CNC carry germline-inactivating mutations in R1a that are spread along the whole coding sequence, with the majority leading to a premature stop codon by nonsense or frame shift (Kirschner et al. 2000, Horvath et al. 2010). A more severe phenotype is observed with in-frame deletion of exon 3 and the c.708+1G>T mutation of PRKAR1A (Groussin et al. 2006). The hot spot c.491-492delTG mutation is most closely associated with lentigines, cardiac myxoma and thyroid tumours when opposed to all other PRKAR1A mutations. Approximately 50\% of pathogenic mutations in PRKAR1A (c.709(-7)del6 or c.1A>G/p.M1V) present with a mild subtype of CNC that is diagnosed before 8 years of age and manifest with seemingly iPPNAD, with or without lentigines. The second locus, CNC type 2 (CNC2), is due to alterations in a yet-unidentified gene on chromosome 2p16, which occurs later in life with a lower frequency of myxomas, schwannomas, thyroid tumours 
Table 1 Endocrine tumour predisposition syndromes.

\begin{tabular}{|c|c|c|c|c|c|}
\hline Syndrome (inheritance) & Gene & Chr. locus & Endocrine features & $\begin{array}{l}\text { Non-endocrine features } \\
\text { presenting in children and } \\
\text { adolescents }\end{array}$ & OMIM \\
\hline $\begin{array}{l}\text { Beckwith-Wiedemann } \\
\text { syndrome (variable) }\end{array}$ & $\begin{array}{l}\text { CDKN1C, } \\
\text { other }\end{array}$ & $11 \mathrm{p} 15.4$ & $\begin{array}{l}\text { ACC } \\
\text { Cytomegaly of the fetal } \\
\text { adrenal cortex } \\
\text { Hyperinsulinism }\end{array}$ & $\begin{array}{l}\text { Wilms tumour, } \\
\text { hepatoblastoma, } \\
\text { lateralised overgrowth, } \\
\text { macrosomia, macroglossia, } \\
\text { omphalocele/umbilical } \\
\text { hernia, neonatal } \\
\text { hypoglycaemia }\end{array}$ & 130650 \\
\hline Carney complex (AD) & $\begin{array}{l}\text { PRKAR1A, } \\
\text { other }\end{array}$ & $17 q 24.2$ & $\begin{array}{l}\text { PPNAD } \\
\text { Thyroid carcinoma } \\
\text { Pituitary adenoma*,\#,\% }\end{array}$ & $\begin{array}{l}\text { Skin pigmentary anomalies } \\
\text { (lentigines), myxoma of } \\
\text { the heart, breast and skin, } \\
\text { large calcifying Sertoli cell } \\
\text { tumours of the testis, } \\
\text { psammomatous melanotic } \\
\text { schwannomas }\end{array}$ & 160980 \\
\hline $\begin{array}{l}\text { Carney-Stratakis } \\
\text { syndrome (AD) }\end{array}$ & $\begin{array}{l}\text { SDHA } \\
\text { SDHB } \\
\text { SDHC } \\
\text { SDHD }\end{array}$ & $\begin{array}{l}15 p 15.33 \\
1 p 36.13 \\
1 q 23.3 \\
11 q 23.1\end{array}$ & $\begin{array}{l}\text { PPGL/ACT/PBMAH } \\
\text { PPGL/ACT/PBMAH } \\
\text { PPGL/ACT/PBMAH } \\
\text { PPGL/ACT/PBMAH }\end{array}$ & GIST & 606864 \\
\hline Carney triad & $\begin{array}{l}\text { SDHC } \\
\text { promoter } \\
\text { methyla }\end{array}$ & $1 \mathrm{q} 23.3$ & $\begin{array}{l}\text { PPGL } \\
\text { ACA } \\
\text { PBMAH }\end{array}$ & $\begin{array}{l}\text { GIST, pulmonary } \\
\text { chondroma, oesophageal } \\
\text { leiomyoma, sarcoma }\end{array}$ & 604287 \\
\hline DICER1 syndrome (AD) & DICER1 & $14 q 32.13$ & $\begin{array}{l}\text { MNG } \\
\text { DTC } \\
\text { PitB }\end{array}$ & $\begin{array}{l}\text { PPB, oSLCTe, cystic } \\
\text { nephroma, eRMS of the } \\
\text { cervix, CBME, } \\
\text { Pineoblastoma }\end{array}$ & 601200 \\
\hline $\begin{array}{l}\text { Familial adenomatous } \\
\text { polyposis (AD) }\end{array}$ & $A P C$ & $5 q 22.2$ & NMTCc & $\begin{array}{l}\text { Gl adenomas, colorectal } \\
\text { cancer, desmoid tumours, } \\
\text { Gardner fibroma, } \\
\text { hepatoblastoma, } \\
\text { medulloblastoma, } \\
\text { odontomas, osteomas }\end{array}$ & 175100 \\
\hline $\begin{array}{l}\text { Familial isolated pituitary } \\
\text { adenoma (AD) }\end{array}$ & $A I P$ & $11 q 13.2$ & $\begin{array}{l}\text { Pituitary } \\
\text { adenoma*,\#,\%,\&,! }\end{array}$ & - & 102200 \\
\hline Familial PPGL (AD) & $\begin{array}{l}\text { SDHA } \\
\text { SDHB } \\
\text { SDHC } \\
\text { SDHD } \\
\text { SDHAF2 }\end{array}$ & $\begin{array}{l}5 p 15.33 \\
1 p 36.13 \\
1 q 23.3 \\
11 q 23.1 \\
11 q 12.2\end{array}$ & PPGL & $\mathrm{RCC}$ & $\begin{array}{l}\text { A: } 614165 \\
\text { B: } 185470 \\
\text { C: } 602413 \\
\text { D: } 602690 \\
\text { AF2: } 601650\end{array}$ \\
\hline $\begin{array}{l}\text { Hereditary } \\
\text { leiomyomatosis renal } \\
\text { cell carcinoma (AD) }\end{array}$ & $F H$ & $1 q 43$ & $\begin{array}{l}\text { PBMAH } \\
\text { ACT } \\
\text { PPGL }\end{array}$ & $\begin{array}{l}\text { RCC (papillary type II), } \\
\text { cutaneous and uterine } \\
\text { leiomyomatosis }\end{array}$ & 150800 \\
\hline $\begin{array}{l}\text { HyperPTH-jaw tumour } \\
\text { syndrome/familial } \\
\text { isolated hyperPTH (AD) }\end{array}$ & CDC73 & $1 \mathrm{q} 31.2$ & $\begin{array}{l}\text { pHPT } \\
\text { Parathyroid carcinoma }\end{array}$ & $\begin{array}{l}\text { Ossifying fibroma of the } \\
\text { jaw, renal cysts and } \\
\text { tumours }\end{array}$ & $\begin{array}{l}145001 \\
145000\end{array}$ \\
\hline $\begin{array}{l}\text { Li-Fraumeni syndrome } \\
\text { (AD) }\end{array}$ & TP53 & $17 p 13.1$ & $\mathrm{ACC}$ & $\begin{array}{l}\text { Hypodiploid ALL, pre- } \\
\text { menopausal breast cancer, } \\
\text { CPC, brain tumours, bone } \\
\text { and soft-tissue sarcomas }\end{array}$ & 151623 \\
\hline $\begin{array}{l}\text { McCune-Albright } \\
\text { syndrome }\end{array}$ & GNAS & $20 q 13.32$ & $\begin{array}{l}\text { Gonadotropin } \\
\text { independent } \\
\text { precocious puberty } \\
\text { Leydig and/or Sertoli } \\
\text { cell hyperplasia (testis) } \\
\text { Growth hormone excess } \\
\text { Neonatal } \\
\text { hypercorticolism } \\
\text { Pituitary adenoma*,\# }\end{array}$ & $\begin{array}{l}\text { Polyostotic fibrous } \\
\text { dysplasia, CALs }\end{array}$ & 174800 \\
\hline
\end{tabular}


Table 1 Continued.

\begin{tabular}{|c|c|c|c|c|c|}
\hline Syndrome (inheritance) & Gene & Chr. locus & Endocrine features & $\begin{array}{l}\text { Non-endocrine features } \\
\text { presenting in children and } \\
\text { adolescents }\end{array}$ & OMIM \\
\hline $\begin{array}{l}\text { Multiple endocrine } \\
\text { neoplasia type } 1 \text { (AD) }\end{array}$ & MEN1 & $11 q 13.1$ & $\begin{array}{l}\text { GEP NETs (typically } \\
\text { pancreatic) } \\
\text { pHPT/parathyroid } \\
\text { tumours } \\
\text { ACT } \\
\text { Pituitary adenoma*,\#,\%,! }\end{array}$ & $\begin{array}{l}\text { Multiple facial } \\
\text { angiofibromas, } \\
\text { collagenomas, lipomas }\end{array}$ & 131100 \\
\hline $\begin{array}{l}\text { Multiple endocrine } \\
\text { neoplasia type } \\
\text { 2a/familial medullary } \\
\text { thyroid carcinoma (AD) }\end{array}$ & $R E T$ & $10 q 11.21$ & $\begin{array}{l}\text { MTC } \\
\text { Parathyroid adenoma/ } \\
\text { pHPT } \\
\text { PPGL } \\
\text { Pituitary adenoma\% }\end{array}$ & $\begin{array}{l}\text { Cutaneous lichen } \\
\text { amyloidosis }\end{array}$ & $\begin{array}{l}171400 \\
155240\end{array}$ \\
\hline $\begin{array}{l}\text { Multiple endocrine } \\
\text { neoplasia type } 2 b(A D)\end{array}$ & $R E T$ & $10 q 11.21$ & $\begin{array}{l}\text { MTC, C-cell hyperplasia } \\
\text { Pituitary adenoma\% }\end{array}$ & $\begin{array}{l}\text { Lip/tongue/eyelid mucosal } \\
\text { neuromas, medullated } \\
\text { corneal nerve fibres, } \\
\text { marfanoid habitus, } \\
\text { ganglioneuromatosis of } \\
\text { the Gl tract }\end{array}$ & 162300 \\
\hline $\begin{array}{l}\text { Multiple endocrine } \\
\text { neoplasia type } 4 \text { (AD) }\end{array}$ & $\begin{array}{l}\text { CDKN1B, } \\
\text { other }\end{array}$ & $12 \mathrm{p} 13.1$ & $\begin{array}{l}\text { Parathyroid tumours/ } \\
\text { pHPT } \\
\text { ACTd } \\
\text { NETd } \\
\text { Pituitary adenoma*,\%,\&,! } \\
\text { Differentiated thyroid } \\
\text { carcinomab,d }\end{array}$ & $\begin{array}{l}\text { Tumours of the kidney, } \\
\text { ovary, meninges }\end{array}$ & 610755 \\
\hline $\begin{array}{l}\text { Neurofibromatosis type } 1 \\
\text { (AD) }\end{array}$ & $N F 1$ & $17 q 11.2$ & PPGL & $\begin{array}{l}\text { CALs, axillary/inguinal } \\
\text { freckling, neurofibroma, } \\
\text { MPNST, lisch nodules, OPG, } \\
\text { learning disabilities }\end{array}$ & 162200 \\
\hline $\begin{array}{l}\text { PTEN hamartoma tumour } \\
\text { syndrome (AD) }\end{array}$ & PTEN & $10 q 23.31$ & $\begin{array}{l}\text { Nodular thyroid } \\
\text { hyperplasia } \\
\text { Thyroid carcinoma }\end{array}$ & $\begin{array}{l}\text { Macrocephaly, autism/ } \\
\text { developmental delay, skin } \\
\text { features (oral papillomas, } \\
\text { trichilemmomas, lipomas, } \\
\text { penile freckling), Gl } \\
\text { polyps, arteriovenous } \\
\text { malformations, } \\
\text { hemangioma }\end{array}$ & 601728 \\
\hline von Hippel-Lindau (AD) & $V H L$ & $3 p 25.3$ & $\begin{array}{l}\text { Pancreatic NETs } \\
\text { PPGL }\end{array}$ & $\begin{array}{l}\text { Renal cysts, RCC (clear cell), } \\
\text { hemangioblastoma (retina/ } \\
\text { CNS) endolymphatic sac } \\
\text { tumours, pancreatic cysts, } \\
\text { cystadenomas of the } \\
\text { epididymis and broad } \\
\text { ligament }\end{array}$ & 193300 \\
\hline $\begin{array}{l}\text { X-linked acrogigantism } \\
\text { (sporadic }>A D)\end{array}$ & GPR101 & Xq26.3 & Pituitary adenoma*,\# & None & 300942 \\
\hline
\end{tabular}

aRecently described in some cases; brarely reported; ccribriform-morular variant is suggestive of familial adenomatous polyposis; described in adults; ecan include endocrine manifestations; *somatotropinoma; "somatomammotropinoma; \%corticotropinoma; !prolactinoma; \&non-functional adenoma. ACA, adrenocortical adenoma; ACC, adrenocortical carcinoma; ACT, adrenocortical tumour; ALL, acute lymphoblastic leukaemia; CALs, café-au-lait spots; CBME, ciliary body medulloepithelioma; CPC, choroid plexus carcinoma; GEP NETs, gastro-entero-pancreatic neuroendocrine tumours; GI, gastrointestinal; GIST, gastrointestinal stromal tumour; DTC, differentiated thyroid carcinoma; eRMS, embryonal rhabdomyosarcoma; MNG, multinodular goitre; MPNST, malignant peripheral nerve sheath tumour; MTC, medullary thyroid carcinoma; NMTC, non-medullary thyroid carcinoma; oSLCT, ovarian Sertoli-Leydig cell tumour; OPG, optic pathway glioma; PBMAH, primary bilateral macronodular adrenocortical hyperplasia; pHPT, primary hyperparathyroidism; PitB, pituitary blastoma; PPB, pleuropulmonary blastoma; PPNAD, primary pigmented nodular adrenocortical disease; PPGL, pheochromocytoma and paraganglioma; PTEN, phosphatase and tensin homologue; RCC, renal cell carcinoma.

and LCCSCT. CNC type 3 (CNC3) is due to PRKACB or PRKACA amplification. Inactivating mutations in the highly polymorphic PDE11A were also reported in patients with PPNAD, likely representing modifier genes
(Libe et al. 2011). CNC predisposes to the development of benign and malignant thyroid disease, typically in a multifocal pattern (Carney et al. 2018). The incidence of DTC, both PTC and FTC, is between 2.5 and 5\% in patients 
with CNC, and thyroid tumours have been reported in patients as young as 13 years (Radin \& Kempf 1995). With the advent of neck ultrasound surveillance protocols, $60-75 \%$ of patients are found to have thyroid pathology, most commonly multiple adenomatous nodules and follicular adenoma (Stratakis et al. 1997, Dotto \& Nose 2008). Paediatric patients with CNC may also present with failure to thrive (Tirosh et al. 2018). The diagnosis of $\mathrm{CNC}$ is established if two or more of major manifestations exist (Stratakis et al. 1993).

\section{Hereditary leiomyomatosis and renal cell cancer}

While the predominant clinical manifestations of hereditary leiomyomatosis and renal cell cancer (HLRCC) are cutaneous and uterine leiomyomas and renal cell carcinoma, it is estimated that $8 \%$ of patients with HLRCC develop adrenocortical lesions, including PBMAH, or isolated non-functional adrenal nodularity (Matyakhina et al. 2005). A handful of cases of pheochromocytoma, paraganglioma as well as one case describing an ACC have been described in patients with HLRCC in the recent literature (Clark et al. 2014, Guo et al. 2017). HLRCC is an autosomal dominant disorder caused by a pathogenic germline variant in the tumour suppressor gene fumarate hydratase $(F H)$. Alterations in $F H$ cause activation of the hypoxia-induced factor 1 pathway that lead to tumourigenesis through enhanced glycolytic activity, neovascularisation and downregulation of apoptotic mechanisms. Clinical diagnostic criteria were proposed by Smit et al. (2011) and include the features described in Table 1.

\section{Carney-Stratakis syndrome}

Carney-Stratakis syndrome (CSS) is a rare autosomal dominant syndrome due to germline pathogenic variants in $S D H A, S D H B, S D H C$ or $S D H D$ (collectively referred to as SDHx) that predisposes to gastrointestinal tumours (GISTs), paragangliomas and adrenocortical tumours (Carney \& Stratakis 2002). These mutations result in destabilisation of the mitochondrial complex and impaired SDH protein expression. SDHD/KIT double-mutated GISTs have also been reported. CSS should be suspected in an individual with early-onset paraganglioma or GISTs (particularly if they co-exist). The diagnosis of CSS is made by clinical, radiologic and immunohistochemical analysis. GISTs that are KIT- and PDGFRA mutation negative should raise suspicion for CSS. Absence of SDHB tumour staining in CSS tumours, an indicator of complex II disruption, is a reliable marker for the diagnosis of CSS in the right clinical setting (Gaal et al. 2011).

\section{Carney triad}

Carney triad (CT) is a rare sporadic condition that predisposes to hamartomatous lesions in various organs (Table 1), with the classic triad of pulmonary chondroma, GIST and PPGL. CT is one of the few conditions that has among its clinical manifestations adrenocortical and medullary involvement, such as coexisting PBMAH or ACA and pheochromocytomas (Carney et al. 1977). In one study of 63 patients, $9.5 \%$ harboured variants in the $S D H A, S D H B, S D H C$ and SDHD or loss of regions on the short arm (1p) and the long arm (1q) of chromosome 1 (Boikos et al. 2016). A recurrent aberrant DNA methylation at the gene locus of $S D H C$ has been described in association with CT (Haller et al. 2014); this is understood to be the molecular signature of CT and serves today as diagnostic for the disease. Activating mutations in KIT- or PDGFRA are not generally observed in CT (Matyakhina et al. 2007), although in a few case reports, somatic KIT mutations have been seen in CT-associated GISTs.

\section{Familial hyperaldosteronism}

Familial hyperaldosteronism represents a rare group of autosomal dominant disorders that are estimated to affect $<2 \%$ of patients with primary aldosteronism. Familial hyperaldosteronism type 1 (FH-I), previously known as glucocorticoid-remediable aldosteronism (GRA), is an autosomal dominant condition that is characterised by severe early-onset primary aldosteronism ( $<20$ years old) due to a chimeric fusion of CYP11B2 and CYP11B1. This genetic alteration renders the aldosterone synthase hybrid gene to be under the regulation of ACTH rather than the renin-angiotensin system (Lifton et al. 1992), leading to increased production of aldosterone and hybrid steroids, such as 18-oxocortisol and 18-hydroxycortisol. Significant phenotypic and biochemical heterogeneity exist, in that some individuals may never develop hypertension. Adrenocortical tumours have been reported in association with FH-I (Jeunemaitre et al. 1995). A family history of primary aldosteronism with or without early cerebral haemorrhage ( $<40$ years) from intracranial aneurysms or haemorrhagic strokes should raise the suspicion for FH-I.

Familial hyperaldosteronism type 2 (FH-II) is the most common form of the disease that arises due to alterations in a yet-unidentified gene on chromosome $7 \mathrm{p} 22$ and characterised by adult-onset hyperaldosteronism from adrenocortical hyperplasia, aldosterone-producing 
adenoma or both (Torpy et al. 1998, Lafferty et al. 2000). Recently, a multiplex family with FH-II had 8 probands with novel heterozygous variants in CLCN2, which encodes a voltage-gated chloride channel expressed in adrenal glomerulosa (Scholl et al. 2018). Familial hyperaldosteronism type 3 (FH-III) is caused by germline heterozygous mutations in KCNJ5, encoding the potassium channel Kir3.4, which presents in childhood or young adults with severe hypertension and metabolic derangements due to adrenocortical hyperplasia (Geller et al. 2008, Monticone et al. 2017). Familial hyperaldosteronism type 4 (FH-IV) has been recently described due to germline gain-of-function mutations in $\mathrm{CACNA1H}$ and characterised by early-onset primary aldosteronism from adrenocortical hyperplasia and seizures (Scholl et al. 2015).

\section{Other familial pheochromocytoma and paraganglioma syndromes}

Familial pheochromocytoma and paraganglioma (PPGL) syndromes are characterised by pheochromocytomas and paragangliomas due to germline pathogenic variants in four nuclear genes that encode the four subunits of the mitochondrial enzyme succinate dehydrogenase (SDH), collectively referred to as $S D H x$. These genes include $S D H A$ (PGL5), SDHB (PGL4), SDHC (PGL3) and SDHD (PGL1). Alterations in SDHAF2 (PGL2) leads to a dysfunctional protein required for flavination of SDHA (Hao et al. 2009). When compared to adults, paediatric patients with PPGLs carry a higher prevalence of hereditary, extra-adrenal and metastatic PPGLs (Pamporaki et al. 2017). Additionally, most paediatric patients with metastatic PPGL had primary extra-adrenal tumours and harboured $S D H B$ (PGL4) mutations (King et al. 2011).

\section{Neurofibromatosis type 1}

Neurofibromatosis type 1 (NF1) is an autosomal dominant syndrome that affects $1 / 3000$ individuals and caused by inactivating mutations in the NF1 gene (Evans et al. 2010). Approximately half of cases result from de novo mutation in NF1 (Evans et al. 2010). The NF1 gene encodes neurofibromin, which is normally involved in the downregulation of the RAS/MAPK signalling pathway. NF1-inactivating mutations result in the constitutive upregulation of $R A S$, an important oncogene located upstream of mTOR (Martin etal. 1990). Only 6\% of patients with NF1 develop PPGLs (Walther et al. 1999a), likely representing an underestimate of the prevalence in this population (Fishbein \& Nathanson 2012). PPGLs typically develop from the 4th decade onwards, are unilateral, and localised to the adrenal glands in $~ 90 \%$ of cases (Bausch et al. 2006). NF1 was identified in 4\% of adolescent cases of pheochromocytomas (age range 14-17 years); these tumours had a tendency for higher malignancy potential (Bausch et al. 2014, Giovannoni et al. 2014). A poor genotype-phenotype correlation exist between NF1 mutations and PPGL development (Tonsgard et al. 1997). Other manifestations of NF1 are featured in Table 1.

\section{von Hippel-Lindau}

The von Hippel-Lindau (VHL) tumour spectrum classically includes retinal, cerebellar and spinal hemangioblastomas, endolymphatic sac tumours, clear cell renal cell carcinoma (ccRCC), PPGL, pancreatic and renal cysts, non-functional pNET and epididymal and broad ligament cystadenoma. These tumours could be challenging to treat as they may present in surgically unresectable areas that rapidly grow and cause mass effects. CNS hemangioblastoma followed by ccRCC are the leading causes of mortality in patients with VHL.

Genotype-phenotype correlations have been clearly defined in VHL and are stratified into two main disease subtypes clinically differing according to the risk of PPGL development. VHL type 1 and 2 are then subcategorised according to risk of ccRCC and CNS disease. VHL type $1 \mathrm{a}$ and $\mathrm{b}$ are associated with truncating mutations or exon deletions, and gene deletions in VHL, respectively. These subtypes are associated with a lower risk of PPGL development (0.5-10\%) (Nordstrom-O'Brien et al. 2010, Lomte et al. 2017). VHL type 2a, b and c are caused by missense mutations in VHL and associated with $>60 \%$ risk of PPGL development (Chen et al. 1995, Zbar et al. 1996). The risk of PPGL is also reported to vary according to the type of missense mutation, with alterations leading to amino acid changes on the surface of pVHL associated with a higher risk of PPGL when compared to mutations that occur deep within pVHL (Ong et al. 2007).

PPGL develop in approximately $10-20 \%$ of patients with VHL, with the earliest reported cases from age 2 years and a mean age of onset of 20-25 years (Neumann et al. 2002, Sovinz et al. 2010, Bholah \& Bunchman 2017). Approximately $90 \%$ of PPGLs are located within the adrenal glands (Walther et al. 1999b), 67-90\% of which present bilaterally or multifocally (Walther et al. 1999b, Lomte et al. 2017). VHL is an autosomal dominant syndrome that is caused by germline pathogenic variants in VHL, encoding a protein with the same name (pVHL). pVHL is involved in the ubiquitination and degradation 
of the hypoxia inducible factor (HIF), which plays a role in the regulation of gene expression. The prevalence of VHL ranges between 1/36,000 and 1/85,000 (Maher et al. 1991, Maddock et al. 1996). Approximately $80 \%$ of children have an affected parent, whereas 20\% result from de novo mutations in VHL (Richards et al. 1995). Missense mutations account for approximately half of the identified germline pathogenic variants in $V H L$, followed by frameshift mutations, large deletions, nonsense mutations, splice-site mutations and in-frame deletions/ insertions (Nordstrom-O'Brien et al. 2010). By age 18 years, $70 \%$ of VHL carriers develop at least one manifestation of the disease, reaching $87 \%$ by age 60 years (Binderup et al. 2017, Launbjerg et al. 2017).

\section{McCune-Albright syndrome}

McCune-Albright syndrome (MAS) describes the association of polyostotic fibrous dysplasia, caféau-lait macules, precocious puberty and overactive endocrinopathies. Affected individuals also were found to have an increased predisposition of Cushing syndrome in the infantile period from nodular adrenal hyperplasia. The genetic defect is due to a postzygotic gain-of-function point mutations in GNAS, within exon 8 of the Gsa subunit, which leads to constitutive activation of adenyl cyclase (Weinstein et al. 1991). Clinical manifestations of MAS are highly variable and depend on the distribution of somatic mosaic mutations in the various affected tissues. Patients with MAS may also present with non-functional ACAs at any age (Carney et al. 2011).

\section{Thyroid tumours}

\section{Classification and molecular features}

Benign thyroid masses are the most frequent thyroid neoplasms in young patients and include single thyroid nodules (not discussed in this review) and multinodular goitre (MNG). While MNG is frequent in adults, especially in the iodine-deficient population (Garcia-Garcia et al. 2017), it represents approximately $20 \%$ of benign thyroid masses in children often in the context of a positive family history of thyroid disease (Divarci et al. 2017).

Thyroid cancers account for $\sim 3 \%$ of all malignancies in patients aged $<20$ years, $75 \%$ of which develop in the 15- to 19-year age group (Horner et al. 2009). Malignant neoplasms of the thyroid gland can be divided into two main categories: medullary thyroid carcinoma (MTC) originating from neural crest-derived calcitoninproducing $\mathrm{C}$ cells and non-medullary thyroid carcinoma
(NMTC) derived from thyroid follicular cells. The latter is further divided into papillary (PTC) and follicular (FTC) thyroid carcinomas, referred to as differentiated thyroid carcinomas (DTCs). PTC presents with several variants, altogether comprising $80-90 \%$ of all thyroid cancers (Davies \& Welch 2006). Poorly differentiated and anaplastic thyroid cancers account for a small portion of NMTCs. While MTCs represent only 8\% of thyroid malignancies in children and adolescents, they are the most frequent subtype to develop in the first 5 years of life, with a steady decline in incidence with advancing age (Dermody et al. 2016). Childhood cancer survivors are at higher risk of developing thyroid cancer, especially when exposed to therapeutic ionising radiation (Cardis et al. 2005). Currently, thyroid cancer represents $\sim 10 \%$ of all second malignant neoplasms in this population.

While it is well established that thyroid carcinogenesis is the predominant feature of multiple endocrine neoplasia syndromes type 2 , in the past decade, thyroid neoplasms and non-neoplastic pathology, such as goitre, have been progressively recognised as being part of numerous other cancer susceptibility syndromes, especially when occurring in younger patients. DICER1 syndrome is now clearly associated with MNG development in children and young adults. Although most DTCs are thought to arise through non-Mendelian mechanisms even in children, PTEN hamartoma tumour syndrome (PHTS), familial adenomatous polyposis (FAP), CNC, Werner and DICER1 syndromes should now be part of the differential diagnosis in a child with a thyroid mass. Non-syndromic forms of familial NMTCs are also responsible for 5\% of NMTC cases. Approximately $25 \%$ of patients with apparently sporadic MTCs carry an activating germline point mutation in the RET gene that is associated with MEN type $2 \mathrm{~A}, 2 \mathrm{~B}$ and familial MTC (variant of MEN 2A). The finding of a germline pathogenic variant or the recognition of familial thyroid cancer enables the implementation of tumour surveillance strategies and appropriate family counselling. Progress in molecular diagnostic technology has permitted the transition from DNA linkage in the 1990s to direct mutation analysis (Fig. 1) allowing more efficient testing and rapid implementation of surveillance and preventive strategies, the latter proven to decrease mortality in patients with MEN2.

While it is widely accepted that MTC and NMTC present with distinct clinical and pathological features, the study of the somatic landscape of thyroid tumours have led to further understanding of their altered 
Table 2 Somatic alterations in thyroid tumours.

\begin{tabular}{|c|c|c|c|c|c|}
\hline Somatic alterations & PTC & FTC & PDTC/ATC & MTC & $\begin{array}{l}\text { Examples of targeted agents for the } \\
\text { treatment of thyroid carcinoma }\end{array}$ \\
\hline \multicolumn{6}{|l|}{ RAS/MAPK pathway } \\
\hline$R E T$ mutations & - & - & - & $95 \%$ (Ped) & $\begin{array}{l}\text { Vandetanib; kinase inhibitor } \\
\text { targeting } R E T \text {-tyrosine kinase }\end{array}$ \\
\hline RAS (NRAS, HRAS, KRAS) & $10-30 \%$ & $30-50 \%$ & $\begin{array}{l}20-50 \%(P D) \\
10-40 \%(A)\end{array}$ & $25 \%$ & $\begin{array}{l}\text { Tipifarnib; RAS inhibitor in phase II } \\
\text { trials for thyroid tumours with } \\
\text { HRAS mutations }\end{array}$ \\
\hline$B R A F$ & $\begin{array}{l}60-80 \% \text { (adult) } \\
<20 \%(\text { ped) }\end{array}$ & $15 \%$ & $\begin{array}{l}10-35 \%(P D) \\
10-50 \%(A)\end{array}$ & - & $\begin{array}{l}\text { Vemurafenib; BRAF inhibitor used } \\
\text { for PTC refractory to radioactive } \\
\text { iodine }\end{array}$ \\
\hline$R E T$ fusions & $12 \%$ & - & - & - & $\begin{array}{l}\text { BLU-667, RET inhibitor evaluated } \\
\text { in a phase } 1 \text { trial }\end{array}$ \\
\hline NTRK 1,3 fusions & $2-15 \%$ * & - & - & - & $\begin{array}{l}\text { Larotrectinib; pan-TRK inhibitor } \\
\text { under investigation in thyroid } \\
\text { cancer }\end{array}$ \\
\hline$A L K$ fusions & $1-7 \%$ & - & $0-10 \%$ & - & $\begin{array}{l}\text { Ceritinib, } A L K \text { inhibitor under } \\
\text { investigation in ATC in patients } \\
\text { with } A L K \text { alterations }\end{array}$ \\
\hline$A K A P 6-B R A F$ & $11 \%$ & - & - & - & - \\
\hline \multicolumn{6}{|l|}{ PI3K-AKT pathway } \\
\hline PIKЗСA & - & $<10 \%$ & $\begin{array}{l}2-10 \% \text { (PD) } \\
10-20 \% \text { (A) }\end{array}$ & - & $\begin{array}{l}\text { CUDC-907, a dual inhibitor of } \\
\text { HDAC and PI3K signalling under } \\
\text { investigation for thyroid cancer }\end{array}$ \\
\hline$A K T 1$ & - & - & $5-10 \%$ & - & $\begin{array}{l}\text { AZD-5363, } A K T \text { inhibitor under } \\
\text { investigation in patients with } \\
A K T \text { mutations }\end{array}$ \\
\hline PTEN & - & $<10 \%$ & $\begin{array}{l}5-20 \%(P D) \\
10-15 \% \text { (A) }\end{array}$ & - & $\begin{array}{l}\text { PI3KB inhibitor GSK-2636771 in } \\
\text { patients with PTEN mutations }\end{array}$ \\
\hline \multicolumn{6}{|l|}{ WNT pathway } \\
\hline CTNNB1 & - & - & $\begin{array}{c}10-20 \%(P D) \\
5-60 \%(A)\end{array}$ & - & - \\
\hline TERT promoter & $5-15 \%$ & $10-35 \%$ & $\begin{array}{l}20-50 \%(P D) \\
30-75 \%(A)\end{array}$ & - & - \\
\hline \multicolumn{6}{|c|}{ Other chromosome rearrangements and point mutations } \\
\hline PAX8-PPARG & - & $30-50 \%$ & - & - & $\begin{array}{l}\text { Efatutazone dihydrochloride, } \\
\text { PPARG agonist investigated for } \\
\text { anaplastic thyroid cancer }\end{array}$ \\
\hline TP53 & - & - & $\begin{array}{l}20-30 \%(P D) \\
50-80 \%(A)\end{array}$ & - & - \\
\hline DICER1 & $10 \%$ & - & - & - & - \\
\hline PRKAR1A & $\sim 0.2 \%$ (amplified) & - & - & - & - \\
\hline
\end{tabular}

Adapted from: Rosenbaum et al. 2005, Sassolas et al. 2012, Xu \& Ghossein 2016, Dom et al. 2018, Giordano 2018 , Wasserman et al. 2018.

* $15 \%$ of radiation induced PTCs; aprevalence of BRAF mutations increases with age.

A, anaplastic; FTC, follicular thyroid carcinoma; PD, poorly differentiated; PDTC/ATC, poorly differentiated thyroid carcinoma/anaplastic thyroid carcinoma; PTC, papillary thyroid carcinoma; MTC, medullary thyroid carcinoma.

molecular pathways and tumourigenic drivers, allowing the integration of targeted therapy in some cases (Roskoski \& Sadeghi-Nejad 2017), especially in aggressive forms of MTC. Numerous somatic changes occur in NMTC and differ according to thyroid cancer histology, presumed aetiology and age group. Table 2 summarises the main somatic changes identified in thyroid tumours and examples of their clinical implications in terms of treatment (Rosenbaum et al. 2005, Sassolas et al. 2012, $\mathrm{Xu}$ \& Ghossein 2016, Dom et al. 2018, Giordano 2018, Wasserman et al. 2018).

http://erc.endocrinology-journals.org https://doi.org/10.1530/ERC-18-0160

\section{Familial syndromes}

\section{DICER1 syndrome}

Numerous reports have described young patients carrying germline DICER1 pathogenic variants with thyroid disease, mostly MNG. Nodular thyroid disease is the most frequent clinically recognised thyroid feature in DICER1 syndrome carriers, which predisposes to thyroid malignancy (Khan et al. 2017b). The cumulative incidence of MNG or thyroidectomy in female carriers of DICER1 pathogenic variants reaches $23 \%$ at 20 years and $50-75 \%$ 
by 40 years. In males, the cumulative incidence of MNG remains between 10 and $14 \%$ by 40 years (Khan et al. $2017 b$ ). DTC of the papillary and follicular subtypes have also been reported in children with DICER1 syndrome (de Kock et al. 2014b). Most of these patients had received chemotherapy and/or radiation as part of treatment of a previous tumour, which has led to the postulation of a potential link between DTC development and chemoand radio-therapeutic agents. However, one family with several children diagnosed with DTC without previous exposure to chemotherapy was reported (Rutter et al. 2016). It is estimated that germline DICER 1 pathogenic variant carriers have a 16- to 18 -fold risk of developing DTC compared to non-carriers (Khan et al. 2017b). In the setting of DICER1 syndrome, thyroid ultrasound with assessment of regional lymph nodes should be initiated at the age of 8 years, and if normal, repeated every 3 years (Schultz et al. 2017). DICER1 syndrome is an autosomal dominant syndrome that is caused by germline pathogenic variants in the DICER1 gene, encoding the DICER1 protein, which is a member of the ribonuclease (RNase) III family of proteins. This protein is responsible for cleaving non-coding small RNA precursors (premiRNA) to generate mature miRNAs that are involved in posttranscriptional regulation of gene expression (Krol et al. 2010). Heterozygotes for germline DICER1 pathogenic variants are predisposed to a variety of benign and malignant tumours including pituitary blastoma, a rare but aggressive brain tumour (Table 1). These DICER1related neoplasms typically harbour a characteristic somatic mutation within the RNase IIIb domain of DICER1 (Heravi-Moussavi et al. 2012, de Kock et al. 2013). Macrocephaly (head circumference $>97$ th perc) has been reported in DICER1 patients (Khan et al. 2017a) and may be a clinical clue to the diagnosis. This is also a typical and even more pronounced clinical feature for PTEN hamartoma tumour syndrome, which is also linked to thyroid tumour development.

\section{PTEN hamartoma tumour syndrome}

Thyroid malignancy may be the first recognised feature of PHTS in children (Smith et al. 2011). PHTS is a group of genetic conditions caused by germline pathogenic variants in the PTEN tumour suppressor gene, with several overlapping clinical phenotypes including Cowden, Cowden-like, Bannayan-Riley-Ruvalcaba, Proteus and Proteus-like syndromes. PTEN encodes a dual specificity phosphatase, involved in the phosphatidylinositol 3-kinase pathway. In germline PTEN carriers, abnormal thyroid gland pathology is reported in $75 \%$ of patients, whereas thyroid cancer is in 14-24\% (Ngeow et al. 2011, Cameselle-Teijeiro et al. 2015). Multifocality, bilaterality and pathological findings in thyroid tumour specimens such as the presence of adenomatous nodules, microadenomas, a background of lymphocytic thyroiditis and PTEN-negative immunostaining are clues for PHTS. The predominant histological subtypes are PTC (60-80\%), FTC (14-45\%) and anaplastic thyroid cancer (6\%). In one multicentre study, $16.7 \%$ of patients with Cowden or Cowden-like syndromes developed thyroid cancer under the age of 18 years (4 PTC, 1 FTC, 1 Hürthle cell carcinoma), with the earliest reported case at the age of 7 years, equivalent to a nine-fold risk of paediatric-onset thyroid carcinoma in PTEN carriers (Ngeow et al. 2011). FTC is considered a major diagnostic feature of PHTS. The median age at diagnosis of thyroid cancer in the overall PTEN mutation-positive Cowden or Cowden-like syndrome cohort was 37.5 years, with a female-to-male ratio of 2.5 to 1 . Another study showed that $0.8 \%$ of consecutive patients with any type of DTC, unselected for age, personal or family history, had a germline pathogenic variant in PTEN (Nagy et al. 2011), both of which had FTC and macrocephaly, while PTEN pathogenic variants were not identified in any of the 402 adults tested in the Cancer Genome Atlas dataset (PMID 25417114, 27959678). Other clinical features suggestive of PHTS are presented in Table 1. Of note, the first manifestations of PHTS in the paediatric age may greatly differ from adult presentations of this syndrome. Macrocephaly, autistic features and developmental delay are recognised as suggestive features in children, while benign and malignant neoplasms account for the majority of the presenting features in adulthood.

\section{Familial adenomatous polyposis}

FAP syndrome is associated with the development of PTC, most notably, the cribriform-morular variant (CMV-PTC), accounting for $<1 \%$ of thyroid tumours. Approximately half of patients who develop CMV-PTC are affected with FAP (Levy et al. 2014, Lam \& Saremi 2017), while $36-73 \%$ of FAP-related PTCs have a CMVPTC subtype (Feng et al. 2015, Uchino et al. 2016). Bilaterality and multicentricity are common features of CMV-PTC in the context of FAP. It is estimated that a third of patients are diagnosed concomitantly with PTC and FAP, a third with PTC and a third with FAP prior to the diagnosis of thyroid cancer. Clinically recognised PTCs develop in $0.4-2.3 \%$ of patients with FAP patients, with a 
female-to-male ratio of 10:1 and occur most often in the first 2 decades (Cetta et al. 2000, Steinhagen et al. 2012). The actual prevalence is higher (2-12\%), as suggested in studies involving thyroid ultrasound surveillance in patients with FAP (Herraiz et al. 2007). Germline pathogenic variants in APC in patients with PTCs are typically located in the $5^{\prime}$ position of the gene, in the similar genomic area usually associated with congenital retinal pigment epithelial hypertrophy (between codons 457 and 1444) (Cetta et al. 2000, Kim et al. 2005). Adrenocortical tumours, such as ACC and PBMAH, have only been reported in adults with FAP (Jasperson et al. 1993). The risk of developing adrenal tumours in FAP is two to four times higher than the general population (Gaujoux et al. 2010, Berthon et al. 2012).

\section{Werner syndrome}

Werner syndrome, caused by biallelic loss-of-function pathogenic variants in $W R N$, is a recessively inherited condition associated with premature features of normal ageing starting in the second decade and the development of multiple cancer types including NMTC. It is estimated that half of persons with Werner syndrome develop at least 1 malignancy by age 40 years with the age range of the first neoplasm between 20 and 69 years (Lauper et al. 2013). In Werner syndrome patients residing in Japan, thyroid carcinoma represented up to $20 \%$ of the reported malignancies, with a striking FTC subtype predominance (Goto et al. 1996, Lauper et al. 2013). In contrast, thyroid carcinoma incidence rates were lower $(6 \%)$ in patients residing outside of Japan, with no apparent predilection for FTC histology, suggesting a genotype-phenotype difference (Ishikawa et al. 1999). The median age for thyroid carcinoma diagnosis in patients with Werner syndrome is 40 years (range 25-46 years), with no paediatric-reported cases.

\section{Familial non-medullary thyroid carcinomas}

Non-syndromic familial non-medullary thyroid carcinomas (FNMTCs) is typically defined by 2 or more first-degree family members affected by thyroid carcinoma without an underlying known syndrome and accounts for to $2.5-10.5 \%$ of all follicular cell origin thyroid cancers (Nose 2008, Bonora et al. 2010). Due to the high prevalence of thyroid cancer, in approximately half of families who have 2 affected members, the association is simply because DTC is not rare and is not attributable to shared genetic factors (Alsanea \& Clark 2001). Familial papillary and Hürthle cell thyroid carcinomas are the predominant subtypes of FNMTC. Younger age of onset, tumour multifocality, bilaterality, lymph node metastasis and extra-thyroidal extension are features of FNMTC (Capezzone et al. 2008, Nose 2008). Furthermore, benign thyroid parenchymal and nodular diseases are often associated with FNMTC (Alsanea \& Clark 2001). Thyroid carcinomas, in the context of FNMTC, behave more aggressively than sporadic forms with poorer survival rates (Alsanea et al. 2000, Capezzone et al. 2008). FNMTC remains a diagnosis in which the genetic basis has not clearly been identified and requires further research. Numerous susceptibility genes have been described in association with FNMTC, such as HABP2 (Gara et al. 2015), FOXE1 (Pereira et al. 2015), TITF-1/NKX2.1 (Ngan et al. 2009), although none have been firmly established as causal drivers of the disease.

\section{Familial syndromes associated with medullary thyroid carcinoma}

MEN2 syndromes are characterised by a striking predisposition to early-onset MTC with or without PPGL and primary hyperparathyroidism (pHPT) and have an estimated prevalence of 1/35,000 (DeLellis et al. 2004). Germline activating mutations in the RET (Rearranged during transfection) proto-oncogene (10q11.2) have been found in $98 \%$ of patients affected with MEN2. RET encodes a receptor tyrosine kinase that is activated by the glial-derived neurotropic factor (GDNF) family of ligands and is involved in signal transduction and activation of the MAPK and other signalling pathways that promote cell growth and survival. It is expressed in neuroendocrine cells such as thyroid $\mathrm{C}$ cells and adrenal medullary cells, neural cells, urogenital tract cells and germ cells of the testis (Santoro et al. 2004, Wells \& Santoro 2009). Over 100 distinct germline pathogenic variants of the RET gene have been identified in patients with hereditary MTC. Molecular categorisation of RET germline variants has become clinically relevant as genotype-phenotype correlations are clearly established, with the type of RET mutation and the underlying mode of RET receptor activation affecting the timing of MTC development. RET mutations are classified as moderate, high or very high risk for MEN2.

Over $90 \%$ of patients with MEN2 syndromes will develop MTC over a lifetime, with it being the most common cause of mortality in patients with multiple endocrine neoplasia type 2A (MEN2A), FMTC and MEN2B. 


\section{MEN2A and familial MTC}

MEN2A and its variant, familial medullary thyroid carcinoma (FMTC), are autosomal dominant conditions caused by germline activating mutations in RET, typically located in the cysteine residues of the extracellular region of the RET protein (Cys 609, 61, 618, 629 and 634) (Eng et al. 1996, Moers et al. 1996). MEN2A is clinically characterised by the development of MTC (90-95\%), PPGL (50\%), pHPT (20-30\%) and by non-malignant features (Table 1) (Eng et al. 1996). Clinical manifestations of MTC are rarely observed in MEN2A carriers in the first decade of life; the prevalence increases with age, $25 \%$ at 13 years and $\sim 70 \%$ at 70 years. By age 35 years, nearly all patients with MEN2A who have not had thyroidectomy will have biochemical evidence of MTC. In contrast, MTC onset often occurs past the 2nd and 3rd decades of life in patients with FMTC. In carriers of MEN2A, timing of prophylactic thyroidectomy can be guided by the patient's genotype and calcitonin levels. In children with 'high risk' alleles, such as mutations in codons 634 and 883, thyroidectomy, often without the need for cervical lymph node dissection, can be achieved by age 5 years or sooner if there is presence of clinical or radiological signs or rising serum calcitonin levels are appreciated (Wasserman et al. 2017, Wells 2018). PPGL may also be the first recognised feature of MEN2A in 13-27\% of cases. Mutations in codon 634 have been associated to a higher incidence of PPGL and pHPT (Eng et al. 1996, American Thyroid Association Guidelines Task Force 2009).

\section{Multiple endocrine neoplasia type 2B}

Patients affected with MEN2B have either inherited a pathogenic RET variant in an autosomal dominant manner (50\%) or have acquired a de novo RET alteration (50\%). As there is such a high de novo mutation rate, a family history of thyroid cancer is often absent, contributing to a late diagnosis of MTC associated with a higher likelihood of metastatic disease and decreased survival. In MEN2B, the onset of MTC is often in the first year of life. A classic p.M918T mutation located within the substrate-binding pocket of the intracellular tyrosine kinase domain of the RET gene is identified in $98 \%$ of patients with MEN2B (Wells et al. 2015). This mutation is considered a 'very high risk' genotype leading to a highly penetrant disease with nearly $100 \%$ likelihood of developing an aggressive form of MTC in early childhood and 50\% risk of developing pheochromocytomas, often with bilateral or multifocal features. For patients with MEN2B, especially those with the classic p.M918T mutation, a total thyroidectomy is recommended in the first year of life, preferably achieved by a surgeon with experience with MEN disorders (Wells et al. 2015). MEN2B-associated features are described in Table 1.

When a child develops an MTC, independently of family history or tumour characteristics, a referral to a medical genetics service should be part of the short-term management. The presence of multifocal and/or bilateral disease, early age of onset of tumour development or evidence of C-cell hyperplasia are clues to the presence of an underlying CPS. Multicentric and bilateral MTC is observed in $30 \%$ of sporadic cases and nearly $100 \%$ of hereditary cases. In families affected with any of the MEN2 syndromes, predictive genetic testing is recommended at childhood, at birth in the case of MEN2B, and before age 5 years in MEN2A or FMTC. MEN2 syndromes are one of the few CPSs with proven preventive measures, associated with improved survival rates and decreased mortality. Genotype-phenotype correlations in the RET gene have influenced timing of thyroidectomy in patients with MEN2 (Wasserman et al. 2017).

\section{Parathyroid tumours}

\section{Classification and molecular features}

Parathyroid adenomas and carcinomas are rare neoplasms in children and adolescents and are most often diagnosed in the evaluation of hypercalcaemia. Approximately $70-90 \%$ of cases of pHPT in children are caused by parathyroid adenomas while $<1 \%$ of cases are associated with parathyroid carcinomas. Parathyroid carcinomas usually develop in the 4th or 5th decade of life with no gender predilection, whereas parathyroid adenomas typically present at an older age and have a female predominance of 3:1. Parathyroid adenomas and carcinomas are characteristically difficult to distinguish on histology, with features such as local invasion and presence of metastatic disease contributing to the final diagnosis (Delellis 2008). It is estimated that $>10 \%$ of apparently sporadic parathyroid tumours are associated with an underlying CPS, namely hyperthyroidismjaw tumour syndrome (HPT-JT), familial isolated hyperparathyroidism (FIHP), MEN1, MEN2A and MEN4 (Belcher et al. 2013, Thakker 2016).

Loss of $11 \mathrm{q}$ and somatic mutations in MEN1, encoding menin, are the most characteristic findings in parathyroid adenomas, with biallelic inactivation of MEN1 identified in up to 35\% of cases (Newey et al. 2012). CCND1, encoding cyclin D1, is also considered as a driver 
mutation in parathyroid adenomas. Overall, $20-40 \%$ of parathyroid adenomas have overexpression of cyclin D1, caused by PTH-CCND1 rearrangements ( $8 \%$ of cases) or DNA amplification (Vasef et al. 1999, Westin et al. 2009). Similarly, Cyclin D1 is overexpressed in most parathyroid carcinomas (Vasef et al. 1999). Other contributors to parathyroid tumourigenesis include CDKN1B, CDKN1A, CDKN2B, CDKN2C, CTNNB1 and LRP5 although their level of involvement requires further studies. Epigenetic alterations including hypermethylation of RIZ1, APC, RASSF1A and HIC1 have been recently described in parathyroid adenomas, but their significance remains unclear (Costa-Guda \& Arnold 2014).

The identification of somatic gene alterations in various benign and malignant forms of neoplasms has been instrumental in understanding the malignant transformation ability of benign tumours, through progression modelling. In these models, early genetic alterations should be found equal or at higher rates as the tumour progresses to a malignant form. MEN1 mutations are found in up to $35 \%$ of parathyroid adenomas and are not identified in parathyroid carcinomas, which suggest that parathyroid adenomas and carcinomas are distinct entities (Farnebo et al. 1998, Costa-Guda et al. 2013). In contrast, progression from parathyroid adenoma to carcinoma has been described in patients with germline pathogenic variants in HRPT2 (Costa-Guda \& Arnold 2014). Sporadic forms of parathyroid carcinoma harbour somatic HRPT2 mutations, encoding parafibromin, in twothirds of cases and are very rare in parathyroid adenomas (Shattuck et al. 2003).

\section{Familial syndromes}

\section{Multiple endocrine neoplasia type 1}

MEN1 is an autosomal dominant syndrome due to heterozygous inactivating germline pathogenic variants of the tumour suppressor gene MEN1 (Chandrasekharappa et al. 1997). Pathogenic alterations in MEN1 are found in approximately 90\% of affected individuals with variable expression with age. The disease prevalence has been estimated at 1/30,000 (Agarwal 2013). Clinical features include the triad of pHPT due to parathyroid hyperplasia (>95\%), pituitary adenomas $(45 \%)$ and neuroendocrine tumours (>30\%). Nonfunctional adrenocortical tumours are not uncommon in MEN1 (Thakker et al. 2012). Gatta-Cherifi et al. reported adrenal enlargement in $20.4 \%(146 / 715)$ of patients with MEN1, due to macronodular ACT $(10.1 \%$ of the cohort) (Gatta-Cherifi et al. 2012). Of the functional ACT, primary aldosteronism and adrenal Cushing syndrome predominates (Gatta-Cherifi et al. 2012, Simonds et al. 2012). Other manifestations of MEN1 are included in Table 1.

Approximately $12 \%$ of MEN1 patients are diagnosed with the disease in the first 2 decades of life (Goudet et al. 2010). pHPT is the earliest recognised feature in patients with MEN1, with the youngest reported cases at age 4 and 8 years (Goudet et al. 2015). In a study evaluating the clinical features of 122 children with MEN1 aged $<21$ years, 75\% had pHPT (Goudet et al. 2015).

\section{Multiple endocrine neoplasia type 4}

It is estimated that 3\% of MEN1-negative patients with MEN1 phenotype harbour heterozygous germline lossof-function CDKN1B mutations, encoding for the cyclindependent kinase inhibitor p27Kip1, which plays a role in cell cycle interactions. Homozygous pathogenic variants in $C D K N 1 B$ were initially identified in a murine model displaying MEN1-like features, which led to the study in humans, linking heterozygous $C D K N 1 B$ mutations to MEN4, the most recent form of MEN (Pellegata et al. 2006). While recessively inherited in rats, this condition was found to be autosomal dominant in humans or acquired sporadically. MEN4 is characterised by the development of parathyroid adenoma and anterior pituitary tumours. pHPT is a key feature present in approximately $80 \%$ of known cases of MEN4, with a later age of onset than that seen in MEN1 (mean 56 vs 25 years) (Lee \& Pellegata 2013, Alrezk et al. 2017). The youngest described case was in a 15-year-old who manifested with symptomatic pHPT (Alrezk et al. 2017). Germline pathogenic variants in CDKN1B also predispose to NET, adrenocortical tumours, neoplasms of the kidney, ovary, thyroid and meninges in adults (Alrezk et al. 2017). MEN4 is a clear example of the progress of genomic medicine as demonstrated by the decreased latency period between the linkage of a $C D K N 1 B$ to this distinct clinical phenotype. (Fig. 1).

\section{Hyperparathyroidism-jaw tumour syndrome and familial isolated hyperparathyroidism}

Hyperparathyroidism-jaw tumour syndrome (HPT-JT) and familial isolated hyperparathyroidism (FIHP) are caused by germline pathogenic variants in the CDC73 tumour suppressor gene encoding parafibromin (Carpten et al. 2002). While FIHP is uniquely associated with pHPT, HPT-JT can also lead to the development of fibro-osseous jaw tumours (25-50\%), renal cysts or tumours (15\%) and uterine fibromas (75\% of females) (Jackson et al. 1990, 
Parfitt et al. 2015). Parathyroid tumours develop in $>90 \%$ of patients with HPT-JT, $15 \%$ of which are parathyroid carcinoma (Jackson et al. 1993, Kutcher et al. 2013). The median age of pHPT diagnosis is 27 years and can occur as young as 7 years (Pichardo-Lowden et al. 2011, Bricaire et al. 2013). Current recommendations support the initiation of tumour surveillance including biochemical screening for pHPT between the ages of 5 and 10 years (Wasserman et al. 2017). In contrast to other genetic conditions, isolated parathyroid adenomas are more often seen than multifocal disease. Approximately $75 \%$ of patients with HPT-JT harbour germline pathogenic variants in the coding region of $C D C 73$, and a smaller proportion of $C D C 73$ negative cases may be related to anomalies in the $C D C 73$ promoter region, noncoding regions or large deletions that could be missed with standard sequencing methods. These conditions are inherited in an autosomal dominant fashion with incomplete penetrance.

\section{Pituitary tumours}

\section{Classification and molecular features}

Adenohypophysis consists of a heterogeneous population of well-differentiated hormone-secreting cells, including somatotrophs, lactotrophs, mammosomatotrophs, corticotrophs, thyrotrophs and gonadotrophs (WatkinsChow \& Camper 1998). Approximately $\sim 3.5-6 \%$ of all surgically treated paediatric pituitary tumours arise from this region (Kane et al. 1994). Paediatric pituitary adenomas are often benign with the most frequently encountered tumours being prolactinomas (most are in adolescents), followed by corticotropinomas and somatotropinomas (Lafferty \& Chrousos 1999). Paediatric nonfunctioning pituitary adenomas are encountered in 3-6\% of all cases (Partington et al. 1994, Mindermann \& Wilson 1995). It is now well established that known underlying germline defects cause approximately onefifth of pituitary adenomas in children and adolescents. Pituitary blastoma, a rare tumour of the pituitary gland classically presenting in the first two years of life, can be initially mistaken for a pituitary adenoma. These tumours are strongly associated with DICER1 syndrome, as described above. Germline pathogenic variants in DICER 1 were identified in $90 \%$ of cases in one study, and is considered a pathognomonic feature of DICER1 syndrome (de Kock et al. 2014a). In this section, we will focus on the genetics of Cushing disease, gigantism and acromegaly.

\section{Cushing disease}

Cushing disease $(\mathrm{CD})$ is an extremely rare paediatric condition with an incidence of 1.2-1.7 cases per million per year (Lindholm et al. 2001) that arise from monoclonal proliferation of corticotrophs leading to endogenous ACTH-dependent hypercortisolemia. Paediatric Cushing syndrome is not clinically distinguishable from adult-onset forms except for the height deceleration. Other clinical features include weight gain, headaches, hypertension, glucose intolerance, and gonadal dysfunction (Lodish et al. 2018). Additionally, children and younger adolescents do not typically report problems with sleep disruption, muscle weakness, memory or cognition (Stratakis 2018). The risk for persistent and recurrent $\mathrm{CD}$ is higher among children of minority ethnic groups. (Gkourogianni et al. 2017).

Genetic alterations in corticotropinomas rarely occur in the known proto-oncogenes or tumour suppressor genes (Table 1) (Hernandez-Ramirez \& Stratakis 2018). In contrast with other pituitary tumour types, the genetic causes of corticotropinomas are largely unknown. Recent studies have shown that the most common genetic alteration found in over one-third of paediatric corticotropinomas were recurrent activating somatic heterozygous driver mutations located in a hotspot region in exon 14 of the ubiquitin-specific protease 8 gene (USP8; chromosome 15q21.2) (Reincke et al. 2015, Faucz et al. 2017). Patients with CD harbouring mutations in USP8 were older at diagnosis with a higher likelihood of recurrence when compared with patients without mutations (Faucz et al. 2017). Moreover, USP8 mutations lead to activation of epidermal growth factor receptor (EGFR) signalling, a potential target for $\mathrm{CD}$ treatment. Recently, our group has identified 4 potentially pathogenic missense germline variants in CDK5 and ABL1 enzyme substrate 1 (CABLES1; chromosome 18q11.2), a tumour suppressor gene that regulates cell cycle progression. Genetic alterations in CABLES1 were found in 4 female patients ( 2 young adults and 2 children) with large corticotropinomas that were difficult to manage (Hernandez-Ramirez et al. 2017). Other somatic events reported in $\mathrm{CD}$ with aggressive behaviour include genetic alterations in p53 (chromosome 17p13.1) tumour suppressor gene (Kawashima et al. 2009).

\section{Multiple endocrine neoplasia}

MEN1 (Rix et al. 2004), MEN2A (Kasturi et al. 2017), MEN2B, and MEN4 predispose to corticotropinoma formation. In one study of 74 patients with sporadic $\mathrm{CD}$ and 4 patients with syndromic $\mathrm{CD}$, pathogenic variants in MEN1 were only identified in 2 syndromic 
patients with genetically confirmed MEN1 relatives (Stratakis et al. 2010), providing evidence for the role of this gene in corticotroph tumourigenesis. Pituitary adenomas are the second most common phenotypic feature of MEN4, affecting $~ 37 \%$ of the reported cases with an age of diagnosis of 30-79 years (Alrezk et al. 2017). $\mathrm{CD}$ has been reported in only one adult with MEN4 due to a heterozygous 19-bp duplication (c.59_77dup19) in CDKN1B, leading to a truncated protein (Georgitsi et al. 2007), and none in paediatric cohorts with CD (Igreja et al. 2009, Stratakis et al. 2010).

\section{Carney complex}

In $\mathrm{CNC}$, previous investigations did not reveal somatic or germline pathogenic variants in PRKAR1A in paediatric CD (Stratakis et al. 2010). Recently, our group reported a paediatric case of $C D$ that was subsequently followed by PPNAD in a patient carrying an inactivating PRKAR1A pathogenic variant (Hernández-Ramírez et al. 2017), providing evidence for the role of PRKAR1A in corticotroph tumourigenesis.

\section{Other syndromes}

Other syndromes that predispose to Cushing disease include MAS (Weinstein et al. 1991, Riminucci et al. 2002), Tuberous Sclerosis (Nandagopal et al. 2007), and DICER1 syndrome (de Kock et al. 2014a, Sahakitrungruang et al. 2014). Familial isolated pituitary adenoma (FIPA), caused by germline pathogenic variants in $A I P$, has only rarely been associated with CD (Beckers et al. 2013).

\section{Gigantism and acromegaly}

Gigantism results from exposure of epiphyseal growth plates before their fusion to growth hormone, while acromegaly occurs after fusion of the plates. The most common pituitary pathology is a benign growth hormone-secreting pituitary adenoma, referred to as a somatotropinoma. The incidence of pituitary gigantism and acromegaly are approximately 8 and 11 cases per million person-years, respectively (Burton et al. 2016). The cyclic AMP pathway is frequently dysregulated in sporadic somatotropinomas; somatic activating mutations in GNAS, which encodes for Gsa, are found in the heterozygous state (Yasufuku-Takano et al. 1999), and on the maternal allele (Hayward et al. 2001), representing the first and largest somatic genetic alteration in somatotropinomas (Landis et al. 1989). Most cases of paediatric gigantism are familial.

\section{X-linked acrogigantism}

$\mathrm{X}$-linked acrogigantism (X-LAG) is the most common cause of early childhood-onset gigantism that is seen in $~ 80 \%$ of pre-pubertal gigantism. X-LAG is caused by GH (and prolactin) over secretion due to a pituitary macroadenoma or hyperplasia (Trivellin et al. 2014), with a median age of onset of 12 months. Germline microduplications on chromosome Xq26.3 causing X-LAG mainly arise de novo. The culprit gene in this duplicated region is GPR101, which codes for an orphan G-protein coupled receptor (GPCR) (Trivellin et al. 2014, Beckers et al. 2015). In sporadic acromegaly, a rare missense variant in GPR101 (p.E308D) was identified in approximately $4 \%$ of cases (Lecoq et al. 2016).

\section{Other syndromes}

Gigantism can occur in association with FIPA, McCuneAlbright syndrome, MEN1, 3PA syndrome (association of familial PPGL and pituitary tumours due to a pathogenic variant in $S D H x), N F 1$, and rarely in MEN4 (Thakker et al 2012, Xekouki et al. 2012, Salenave et al. 2014, Hernandez-Ramirez et al. 2015, Rostomyan et al. 2015, Sambugaro et al. 2015, Alrezk et al. 2017, HannahShmouni et al. 2017). Cambiaso et al. found GH excess in 7 (10.9\%) out of 64 children with NF1 and optic pathway glioma (Cambiaso et al. 2017).

\section{Summary}

The identification of the genes responsible for the various CPSs in this review has enabled the genetic diagnosis and early identification of patients and their at-risk family members. Genetic testing in clinical practice for familial syndrome has become widely spread and considered routine in tertiary medical centres. Most paediatric CPSs are familial and rarely sporadic. When faced with a rare endocrinopathy in paediatrics, such as PPGL, Cushing disease or thyroid cancer, clinicians are encouraged to obtain a detailed family history and pedigree to deduce dominance and distinguish autosomal from X-linked inheritance. Pattern recognition, age of onset, radiological and histopathological features are key in distinguishing between the various CPSs. Thus, when a clinician encounters a paediatric patient with any of the syndromic features, genetic testing and counselling regardless of family history should be considered as many of these conditions may have decreased penetrance and first-degree relatives that are carriers may not be affected. A low threshold for exploring genetic testing is important 
particularly if the clinical phenotype warrants it. Genetic counselling and testing strategies in the paediatric population are not without complexities and ethical challenges which need to be considered. Numerous recent publications and position statements have addressed these issues (Botkin et al. 2015, Botkin 2016, Newson $\&$ Schonstein 2016). Screening should also be offered to a first-degree relative when a germline pathogenic variant in a disease-causing gene has been identified. Additionally, the identification of a germline pathogenic variant should prompt periodic clinical, biochemical and radiological screening for the syndrome in question. Periodic reassessment of the medical literature and raw genetic data is encouraged to identify new genes or syndromes in individuals with a suspected syndrome and an unidentified genetic mutation.

\section{Declaration of interest}

The authors declare that there is no conflict of interest that could be perceived as prejudicing the impartiality of this review.

\section{Funding}

This work was in part supported by the Intramural Research Program (IRP), NICHD, NIH, Bethesda, MD 20892, USA. W D F acknowledges the funding support of the Canadian Institutes of Health Research (FDN: 148390). Dr C Goudie's research was generously funded by the Cedars Cancer Foundation and the Montreal Children's Hospital Foundation as well as the Pediatric Oncology Group of Ontario.

\section{Authors' contribution statement}

C G and F H-S: implicated in all aspects of this review and co-wrote the manuscript; $\mathrm{M} \mathrm{K}$ : contributed to the evidence-based literature review and conception of the tables/figures; W D F and C S: review conception and revision of manuscript.

\section{Acknowledgements}

The authors would like to thank $\mathrm{R}$ de Borga for his assistance with the creation of Figure 1 and S Fahiminiya for help with Table 2.

\section{References}

Agarwal SK 2013 Multiple endocrine neoplasia type 1. Frontiers of Hormone Research 41 1-15. (https://doi.org/10.1159/000345666)

Alencar GA, Lerario AM, Nishi MY, Mariani BM, Almeida MQ Tremblay J, Hamet P, Bourdeau I, Zerbini MC, Pereira MA, et al. 2014 ARMC5 mutations are a frequent cause of primary macronodular adrenal hyperplasia. Journal of Clinical Endocrinology and Metabolism 99 E1501-E1509. (https://doi.org/10.1210/jc.2013-4237)

Alrezk R, Hannah-Shmouni F \& Stratakis CA 2017 MEN4 and CDKN1B mutations: the latest of the MEN syndromes. Endocrine-Related Cancer 24 T195-T208. (https://doi.org/10.1530/ERC-17-0243)
Alsanea O \& Clark OH 2001 Familial thyroid cancer. Current Opinion in Oncology 13 44-51. (https://doi.org/10.1097/00001622-20010100000009)

Alsanea O, Wada N, Ain K, Wong M, Taylor K, Ituarte PH, Treseler PA, Weier HU, Freimer N, Siperstein AE, et al. 2000 Is familial nonmedullary thyroid carcinoma more aggressive than sporadic thyroid cancer? A multicenter series. Surgery 128 1043-1050; discussion 1050-1041. (https://doi.org/10.1067/msy.2000.110848)

Amadou A, Waddington Achatz MI \& Hainaut P 2018 Revisiting tumor patterns and penetrance in germline TP53 mutation carriers: temporal phases of Li-Fraumeni syndrome. Current Opinion in Oncology 30 23-29. (https://doi.org/10.1097/ CCO.0000000000000423)

American Thyroid Association Guidelines Task Force, Kloos RT, Eng C, Evans DB, Francis GL, Gagel RF, Gharib H, Moley JF, Pacini F, Ringel MD, et al. 2009 Medullary thyroid cancer: management guidelines of the American Thyroid Association. Thyroid 19 565-612. (https://doi.org/10.1089/thy.2008.0403)

Assie G, Libe R, Espiard S, Rizk-Rabin M, Guimier A, Luscap W, Barreau O, Lefevre L, Sibony M, Guignat L, et al. 2013 ARMC5 mutations in macronodular adrenal hyperplasia with Cushing's syndrome. New England Journal of Medicine 369 2105-2114. (https:// doi.org/10.1056/NEJMoa1304603)

Azevedo MF, Faucz FR, Bimpaki E, Horvath A, Levy I, de Alexandre RB, Ahmad F, Manganiello V \& Stratakis CA 2014 Clinical and molecular genetics of the phosphodiesterases (PDEs). Endocrine Reviews $\mathbf{3 5}$ 195-233. (https://doi.org/10.1210/er.2013-1053)

Bausch B, Borozdin W, Neumann HP \& European-American Pheochromocytoma Study Group 2006 Clinical and genetic characteristics of patients with neurofibromatosis type 1 and pheochromocytoma. New England Journal of Medicine 354 2729-2731. (https://doi.org/10.1056/NEJMc066006)

Bausch B, Wellner U, Bausch D, Schiavi F, Barontini M, Sanso G, Walz MK, Peczkowska M, Weryha G, Dall'igna P, et al. 2014 Long-term prognosis of patients with pediatric pheochromocytoma Endocrine-Related Cancer 21 17-25. (https://doi.org/10.1530/ERC-130415)

Beckers A, Aaltonen LA, Daly AF \& Karhu A 2013 Familial isolated pituitary adenomas (FIPA) and the pituitary adenoma predisposition due to mutations in the aryl hydrocarbon receptor interacting protein (AIP) gene. Endocrine Reviews 34 239-277. (https://doi. org/10.1210/er.2012-1013)

Beckers A, Lodish MB, Trivellin G, Rostomyan L, Lee M, Faucz FR, Yuan B, Choong CS, Caberg JH, Verrua E, et al. 2015 X-linked acrogigantism syndrome: clinical profile and therapeutic responses. Endocrine-Related Cancer 22 353-367. (https://doi.org/10.1530/ERC15-0038)

Belcher R, Metrailer AM, Bodenner DL \& Stack BC Jr 2013 Characterization of hyperparathyroidism in youth and adolescents: a literature review. International Journal of Pediatric Otorhinolaryngology 77 318-322. (https://doi.org/10.1016/j. ijporl.2012.12.008)

Berthon A, Martinez A, Bertherat J \& Val P 2012 Wnt/beta-catenin signalling in adrenal physiology and tumour development. Molecular and Cellular Endocrinology 351 87-95. (https://doi.org/10.1016/j. mce.2011.09.009)

Beuschlein F, Fassnacht M, Assie G, Calebiro D, Stratakis CA, Osswald A, Ronchi CL, Wieland T, Sbiera S, Faucz FR, et al. 2014 Constitutive activation of PKA catalytic subunit in adrenal Cushing's syndrome. New England Journal of Medicine 370 1019-1028. (https://doi. org/10.1056/NEJMoa1310359)

Bholah R \& Bunchman TE 2017 Review of pediatric pheochromocytoma and paraganglioma. Frontiers in Pediatrics 5 155. (https://doi. org/10.3389/fped.2017.00155)

Binderup ML, Galanakis M, Budtz-Jorgensen E, Kosteljanetz M \& Luise Bisgaard M 2017 Prevalence, birth incidence, and penetrance of von 
Hippel-Lindau disease (vHL) in Denmark. European Journal of Human Genetics 25 301-307. (https://doi.org/10.1038/ejhg.2016.173)

Boikos SA, Xekouki P, Fumagalli E, Faucz FR, Raygada M, Szarek E, Ball E, Kim SY, Miettinen M, Helman LJ, et al. 2016 Carney triad can be (rarely) associated with germline succinate dehydrogenase defects. European Journal of Human Genetics 24 569-573. (https://doi. org/10.1038/ejhg.2015.142)

Bonora E, Tallini G \& Romeo G 2010 Genetic predisposition to familial nonmedullary thyroid cancer: an update of molecular findings and state-of-the-art studies. Journal of Oncology 2010 385206. (https://doi. org/10.1155/2010/385206)

Botkin JR 2016 Ethical issues in pediatric genetic testing and screening. Current Opinion in Pediatrics 28 700-704. (https://doi.org/10.1097/ MOP.0000000000000418)

Botkin JR, Belmont JW, Berg JS, Berkman BE, Bombard Y, Holm IA, Levy HP, Ormond KE, Saal HM, Spinner NB, et al. 2015 Points to consider: ethical, legal, and psychosocial implications of genetic testing in children and adolescents. American Journal of Human Genetics 97 6-21. (https://doi.org/10.1016/j.ajhg.2015.05.022)

Bourdeau I, D'Amour P, Hamet P, Boutin JM \& Lacroix A 2001 Aberrant membrane hormone receptors in incidentally discovered bilateral macronodular adrenal hyperplasia with subclinical Cushing's syndrome. Journal of Clinical Endocrinology and Metabolism 86 5534-5540. (https://doi.org/10.1210/jcem.86.11.8062)

Bourdeau I, Lampron A, Costa MH, Tadjine M \& Lacroix A 2007 Adrenocorticotropic hormone-independent Cushing's syndrome. Current Opinion in Endocrinology, Diabetes and Obesity 14 219-225. (https://doi.org/10.1097/MED.0b013e32814db842)

Bricaire L, Odou MF, Cardot-Bauters C, Delemer B, North MO, Salenave S, Vezzosi D, Kuhn JM, Murat A, Caron P, et al. 2013 Frequent large germline HRPT2 deletions in a French National cohort of patients with primary hyperparathyroidism. Journal of Clinical Endocrinology and Metabolism 98 E403-E408. (https://doi. org/10.1210/jc.2012-2789)

Brioude F, Kalish JM, Mussa A, Foster AC, Bliek J, Ferrero GB, Boonen SE, Cole T, Baker R, Bertoletti M, et al. 2018 Expert consensus document: clinical and molecular diagnosis, screening and management of Beckwith-Wiedemann syndrome: an international consensus statement. Nature Reviews Endocrinology 14 229-249. (https://doi. org/10.1038/nrendo.2017.166)

Burton T, Le Nestour E, Neary M \& Ludlam WH 2016 Incidence and prevalence of acromegaly in a large US health plan database. Pituitary 19 262-267. (https://doi.org/10.1007/s11102-015-0701-2)

Cambiaso P, Galassi S, Palmiero M, Mastronuzzi A, Del Bufalo F, Capolino R, Cacchione A, Buonuomo PS, Gonfiantini MV, Bartuli A, et al. 2017 Growth hormone excess in children with neurofibromatosis type-1 and optic glioma. American Journal of Medical Genetics Part A 173 2353-2358. (https://doi.org/10.1002/ ajmg.a.38308)

Cameselle-Teijeiro J, Fachal C, Cabezas-Agricola JM, Alfonsin-Barreiro N, Abdulkader I, Vega-Gliemmo A \& Hermo JA 2015 Thyroid pathology findings in Cowden syndrome: a clue for the diagnosis of the PTEN hamartoma tumor syndrome. American Journal of Clinical Pathology 144 322-328. (https://doi.org/10.1309/AJCP84INGJUVTBME)

Capezzone M, Marchisotta S, Cantara S, Busonero G, Brilli L, PazaitouPanayiotou K, Carli AF, Caruso G, Toti P, Capitani S, et al. 2008 Familial non-medullary thyroid carcinoma displays the features of clinical anticipation suggestive of a distinct biological entity. Endocrine-Related Cancer 15 1075-1081. (https://doi.org/10.1677/ERC08-0080)

Cardis E, Kesminiene A, Ivanov V, Malakhova I, Shibata Y, Khrouch V, Drozdovitch V, Maceika E, Zvonova I, Vlassov O, et al. 2005 Risk of thyroid cancer after exposure to 131I in childhood. Journal of the National Cancer Institute 97 724-732. (https://doi.org/10.1093/jnci/ dji129)
Carney JA \& Stratakis CA 2002 Familial paraganglioma and gastric stromal sarcoma: a new syndrome distinct from the Carney triad. American Journal of Medical Genetics 108 132-139. (https://doi. org/10.1002/ajmg.10235)

Carney JA, Sheps SG, Go VL \& Gordon H 1977 The triad of gastric leiomyosarcoma, functioning extra-adrenal paraganglioma and pulmonary chondroma. New England Journal of Medicine 296 1517-1518. (https://doi.org/10.1056/NEJM197706302962609)

Carney JA, Young WF \& Stratakis CA 2011 Primary bimorphic adrenocortical disease: cause of hypercortisolism in McCune-Albright syndrome. American Journal of Surgical Pathology 35 1311-1326. (https://doi.org/10.1097/PAS.0b013e31821ec4ce)

Carney JA, Lyssikatos C, Seethala RR, Lakatos P, Perez-Atayde A, Lahner H \& Stratakis CA 2018 The spectrum of thyroid gland pathology in carney complex: the importance of follicular carcinoma. American Journal of Surgical Pathology 42 587-594. (https://doi.org/10.1097/PAS.0000000000000975)

Carpten JD, Robbins CM, Villablanca A, Forsberg L, Presciuttini S, Bailey-Wilson J, Simonds WF, Gillanders EM, Kennedy AM, Chen JD, et al. 2002 HRPT2, encoding parafibromin, is mutated in hyperparathyroidism-jaw tumor syndrome. Nature Genetics 32 676-680. (https://doi.org/10.1038/ng1048)

Cetta F, Montalto G, Gori M, Curia MC, Cama A \& Olschwang S 2000 Germline mutations of the APC gene in patients with familial adenomatous polyposis-associated thyroid carcinoma: results from a European Cooperative Study. Journal of Clinical Endocrinology and Metabolism 85 286-292. (https://doi.org/10.1210/jcem.85.1.6254)

Chandrasekharappa SC, Guru SC, Manickam P, Olufemi SE, Collins FS, Emmert-Buck MR, Debelenko LV, Zhuang Z, Lubensky IA, Liotta LA et al. 1997 Positional cloning of the gene for multiple endocrine neoplasia-type 1. Science 276 404-407. (https://doi.org/10.1126/ science.276.5311.404)

Chen F, Kishida T, Yao M, Hustad T, Glavac D, Dean M, Gnarra JR, Orcutt ML, Duh FM, Glenn G, et al. 1995 Germline mutations in the von Hippel-Lindau disease tumor suppressor gene: correlations with phenotype. Human Mutation 5 66-75. (https://doi.org/10.1002/ humu.1380050109)

Clark GR, Sciacovelli M, Gaude E, Walsh DM, Kirby G, Simpson MA, Trembath RC, Berg JN, Woodward ER, Kinning E, et al. 2014 Germline FH mutations presenting with pheochromocytoma. Journal of Clinical Endocrinology and Metabolism 99 E2046-E2050. (https:// doi.org/10.1210/jc.2014-1659)

Correa R, Zilbermint M, Berthon A, Espiard S, Batsis M, Papadakis G, Xekouki P, Lodish MB, Bertherat J, Faucz FR, et al. 2015 The ARMC5 gene shows extensive genetic variance in primary macronodular adrenocortical hyperplasia. European Journal of Endocrinology 173 435-440. (https://doi.org/10.1530/EJE-15-0205)

Costa-Guda J \& Arnold A 2014 Genetic and epigenetic changes in sporadic endocrine tumors: parathyroid tumors. Molecular and Cellular Endocrinology 386 46-54. (https://doi.org/10.1016/j. mce.2013.09.005)

Costa-Guda J, Imanishi Y, Palanisamy N, Kawamata N, Phillip Koeffler H, Chaganti RS \& Arnold A 2013 Allelic imbalance in sporadic parathyroid carcinoma and evidence for its de novo origins. Endocrine 44 489-495. (https://doi.org/10.1007/s12020-013-9903-4)

Custodio G, Komechen H, Figueiredo FR, Fachin ND, Pianovski MA \& Figueiredo BC 2012 Molecular epidemiology of adrenocortical tumors in southern Brazil. Molecular and Cellular Endocrinology 351 44-51. (https://doi.org/10.1016/j.mce.2011.10.019)

Custodio G, Parise GA, Kiesel Filho N, Komechen H, Sabbaga CC, Rosati R, Grisa L, Parise IZ, Pianovski MA, Fiori CM, et al. 2013 Impact of neonatal screening and surveillance for the TP53 R337H mutation on early detection of childhood adrenocortical tumors. Journal of Clinical Oncology 31 2619-2626. (https://doi.org/10.1200/ JCO.2012.46.3711)
2018 Society for Endocrinology Published by Bioscientifica Ltd. Printed in Great Britain 
Davies L \& Welch HG 2006 Increasing incidence of thyroid cancer in the United States, 1973-2002. JAMA 295 2164-2167. (https://doi. org/10.1001/jama.295.18.2164)

de Kock L, Plourde F, Carter MT, Hamel N, Srivastava A, Meyn MS, Arseneau J, Bouron-Dal Soglio D \& Foulkes WD 2013 Germ-line and somatic DICER1 mutations in a pleuropulmonary blastoma. Pediatric Blood and Cancer 60 2091-2092. (https://doi.org/10.1002/pbc.24692)

de Kock L, Sabbaghian N, Plourde F, Srivastava A, Weber E, Bouron-Dal Soglio D, Hamel N, Choi JH, Park SH, Deal CL, et al. 2014a Pituitary blastoma: a pathognomonic feature of germ-line DICER1 mutations. Acta Neuropathologica 128 111-122. (https://doi.org/10.1007/s00401014-1285-z)

de Kock L, Sabbaghian N, Soglio DB, Guillerman RP, Park BK, Chami R, Deal CL, Priest JR \& Foulkes WD 2014b Exploring the association between DICER1 mutations and differentiated thyroid carcinoma. Journal of Clinical Endocrinology and Metabolism 99 E1072-E1077. (https://doi.org/10.1210/jc.2013-4206)

DeLellis RA 2008 Challenging lesions in the differential diagnosis of endocrine tumors: parathyroid carcinoma. Endocrine Pathology 19 221-225. (https://doi.org/10.1007/s12022-008-9050-2)

DeLellis RA, Lloyd RV, Heitz PU \& Eng C 2004 Pathology and Genetics: Tumours of the Endocrine Organs. World Health Organization Classification of Tumours Series. Lyon, France: IARC Press.

Dermody S, Walls A \& Harley EH Jr 2016 Pediatric thyroid cancer: an update from the SEER database 2007-2012. International Journal of Pediatric Otorhinolaryngology 89 121-126. (https://doi.org/10.1016/j. ijporl.2016.08.005)

Divarci E, Celtik U, Dokumcu Z, Ergun O, Ozok G, Ozen S, Simsek DG, Darcan S, Cetingul N, Oral A, et al. 2017 Management of childhood thyroid nodules: surgical and endocrinological findings in a large group of cases. Journal of Clinical Research in Pediatric Endocrinology 9 222-228. (https://doi.org/10.4274/jcrpe.4272)

Dom G, Frank S, Floor S, Kehagias P, Libert F, Hoang C, Andry G, Spinette A, Craciun L, de Saint Aubin N, et al. 2018 Thyroid follicular adenomas and carcinomas: molecular profiling provides evidence for a continuous evolution. Oncotarget 9 10343-10359. (https://doi.org/10.18632/oncotarget.23130)

Dotto J \& Nose V 2008 Familial thyroid carcinoma: a diagnostic algorithm. Advances in Anatomic Pathology 15 332-349. (https://doi. org/10.1097/PAP.0b013e31818a64af)

Else T 2012 Association of adrenocortical carcinoma with familial cancer susceptibility syndromes. Molecular and Cellular Endocrinology 351 66-70. (https://doi.org/10.1016/j.mce.2011.12.008)

Eng C, Clayton D, Schuffenecker I, Lenoir G, Cote G, Gagel RF, van Amstel HK, Lips CJ, Nishisho I, Takai SI, et al. 1996 The relationship between specific RET proto-oncogene mutations and disease phenotype in multiple endocrine neoplasia type 2. International RET mutation consortium analysis. JAMA 276 1575-1579. (https://doi. org/10.1001/jama.1996.03540190047028)

Espiard S, Drougat L, Libe R, Assie G, Perlemoine K, Guignat L, Barrande G, Brucker-Davis F, Doullay F, Lopez S, et al. 2015 ARMC5 mutations in a large cohort of primary macronodular adrenal hyperplasia: clinical and functional consequences. Journal of Clinical Endocrinology and Metabolism 100 E926-E935. (https://doi. org/10.1210/jc.2014-4204)

Evans DG, Howard E, Giblin C, Clancy T, Spencer H, Huson SM \& Lalloo F 2010 Birth incidence and prevalence of tumor-prone syndromes: estimates from a UK family genetic register service. American Journal of Medical Genetics Part A 152A 327-332. (https:// doi.org/10.1002/ajmg.a.33139)

Farnebo F, Teh BT, Kytola S, Svensson A, Phelan C, Sandelin K, Thompson NW, Hoog A, Weber G, Farnebo LO, et al. 1998 Alterations of the MEN1 gene in sporadic parathyroid tumors. Journal of Clinical Endocrinology and Metabolism 83 2627-2630. (https://doi.org/10.1210/jcem.83.8.4846)
Faucz FR, Zilbermint M, Lodish MB, Szarek E, Trivellin G, Sinaii N, Berthon A, Libe R, Assie G, Espiard S, et al. 2014 Macronodular adrenal hyperplasia due to mutations in an armadillo repeat containing 5 (ARMC5) gene: a clinical and genetic investigation. Journal of Clinical Endocrinology and Metabolism 99 E1113-E1119. (https://doi.org/10.1210/jc.2013-4280)

Faucz FR, Tirosh A, Tatsi C, Berthon A, Hernandez-Ramirez LC, Settas N, Angelousi A, Correa R, Papadakis GZ, Chittiboina P, et al. 2017 Somatic USP8 gene mutations are a common cause of pediatric Cushing disease. Journal of Clinical Endocrinology and Metabolism 102 2836-2843. (https://doi.org/10.1210/jc.2017-00161)

Feng X, Milas M, O’Malley M, LaGuardia L, Berber E, Jin J, Metzger R, Mitchell J, Shin J, Burke CA, et al. 2015 Characteristics of benign and malignant thyroid disease in familial adenomatous polyposis patients and recommendations for disease surveillance. Thyroid $\mathbf{2 5}$ 325-332. (https://doi.org/10.1089/thy.2014.0107)

Fishbein L \& Nathanson KL 2012 Pheochromocytoma and paraganglioma: understanding the complexities of the genetic background. Cancer Genetics 205 1-11. (https://doi.org/10.1016/j. cancergen.2012.01.009)

Fragoso MC, Domenice S, Latronico AC, Martin RM, Pereira MA, Zerbini MC, Lucon AM \& Mendonca BB 2003 Cushing's syndrome secondary to adrenocorticotropin-independent macronodular adrenocortical hyperplasia due to activating mutations of GNAS1 gene. Journal of Clinical Endocrinology and Metabolism 88 2147-2151. (https://doi.org/10.1210/jc.2002-021362)

Francis SH, Blount MA \& Corbin JD 2011 Mammalian cyclic nucleotide phosphodiesterases: molecular mechanisms and physiological functions. Physiological Reviews 91 651-690. (https://doi.org/10.1152/ physrev.00030.2010)

Gaal J, Stratakis CA, Carney JA, Ball ER, Korpershoek E, Lodish MB, Levy I, Xekouki P, van Nederveen FH, den Bakker MA, et al. 2011 SDHB immunohistochemistry: a useful tool in the diagnosis of Carney-Stratakis and Carney triad gastrointestinal stromal tumors. Modern Pathology 24 147-151. (https://doi.org/10.1038/ modpathol.2010.185)

Gara SK, Jia L, Merino MJ, Agarwal SK, Zhang L, Cam M, Patel D \& Kebebew E 2015 Germline HABP2 mutation causing familial nonmedullary thyroid cancer. New England Journal of Medicine $\mathbf{3 7 3}$ 448-455. (https://doi.org/10.1056/NEJMoa1502449)

Garcia-Garcia E, Lopez-Gonzalez M, Cabello-Laureano R \& NavarroGonzalez E 2017 Multinodular goiter in children: treatment controversies. Journal of Pediatric Endocrinology and Metabolism 30 847-850. (https://doi.org/10.1515/jpem-2016-0368)

Gatta-Cherifi B, Chabre O, Murat A, Niccoli P, Cardot-Bauters C, Rohmer V, Young J, Delemer B, Du Boullay H, Verger MF, et al. 2012 Adrenal involvement in MEN1. Analysis of 715 cases from the Groupe d'etude des Tumeurs Endocrines database. European Journal of Endocrinology 166 269-279. (https://doi.org/10.1530/EJE-11-0679)

Gaujoux S, Pinson S, Gimenez-Roqueplo AP, Amar L, Ragazzon B, Launay P, Meatchi T, Libe R, Bertagna X, Audebourg A, et al. 2010 Inactivation of the APC gene is constant in adrenocortical tumors from patients with familial adenomatous polyposis but not frequent in sporadic adrenocortical cancers. Clinical Cancer Research $\mathbf{1 6}$ 5133-5141. (https://doi.org/10.1158/1078-0432.CCR-10-1497)

Geller DS, Zhang J, Wisgerhof MV, Shackleton C, Kashgarian M \& Lifton RP 2008 A novel form of human mendelian hypertension featuring nonglucocorticoid-remediable aldosteronism. Journal of Clinical Endocrinology and Metabolism 93 3117-3123. (https://doi. org/10.1210/jc.2008-0594)

Georgitsi M, Raitila A, Karhu A, van der Luijt RB, Aalfs CM, Sane T, Vierimaa O, Makinen MJ, Tuppurainen K, Paschke R, et al. 2007 Germline CDKN1B/p27Kip1 mutation in multiple endocrine neoplasia. Journal of Clinical Endocrinology and Metabolism 92 3321-3325. (https://doi.org/10.1210/jc.2006-2843) (c) 2018 Society for Endocrinology Published by Bioscientifica Ltd. Printed in Great Britain 
Giordano TJ 2018 Genomic hallmarks of thyroid neoplasia. Annual Review of Pathology 13 141-162. (https://doi.org/10.1146/annurevpathol-121808-102139)

Giovannoni I, Callea F, Boldrini R, Inserra A, Cozza R \& Francalanci P 2014 Malignant pheochromocytoma in a 16-year-old patient with neurofibromatosis type 1. Pediatric and Developmental Pathology 17 126-129. (https://doi.org/10.2350/13-10-1397-CR.1)

Gkourogianni A, Sinaii N, Jackson SH, Karageorgiadis AS, Lyssikatos C, Belyavskaya E, Keil MF, Zilbermint M, Chittiboina P, Stratakis CA, et al. 2017 Pediatric Cushing disease: disparities in disease severity and outcomes in the Hispanic and African-American populations. Pediatric Research 82 272-277. (https://doi.org/10.1038/pr.2017.58)

Gonzalez KD, Noltner KA, Buzin CH, Gu D, Wen-Fong CY, Nguyen VQ, Han JH, Lowstuter K, Longmate J, Sommer SS, et al. 2009 Beyond Li Fraumeni syndrome: clinical characteristics of families with p53 germline mutations. Journal of Clinical Oncology 27 1250-1256. (https://doi.org/10.1200/JCO.2008.16.6959)

Goto M, Miller RW, Ishikawa Y \& Sugano H 1996 Excess of rare cancers in Werner syndrome (adult progeria). Cancer Epidemiology, Biomarkers and Prevention 5 239-246.

Goudet P, Murat A, Binquet C, Cardot-Bauters C, Costa A, Ruszniewski P, Niccoli P, Menegaux F, Chabrier G, Borson-Chazot F, et al. 2010 Risk factors and causes of death in MEN1 disease. A GTE (Groupe d'Etude des Tumeurs Endocrines) cohort study among 758 patients. World Journal of Surgery 34 249-255. (https://doi.org/10.1007/s00268-0090290-1)

Goudet P, Dalac A, Le Bras M, Cardot-Bauters C, Niccoli P, LevyBohbot N, du Boullay H, Bertagna X, Ruszniewski P, BorsonChazot F, et al. 2015 MEN1 disease occurring before 21 years old: a 160-patient cohort study from the Groupe d'etude des Tumeurs Endocrines. Journal of Clinical Endocrinology and Metabolism 100 1568-1577. (https://doi.org/10.1210/jc.2014-3659)

Grobner SN, Worst BC, Weischenfeldt J, Buchhalter I, Kleinheinz K, Rudneva VA, Johann PD, Balasubramanian GP, Segura-Wang M, Brabetz S, et al. 2018 The landscape of genomic alterations across childhood cancers. Nature 555 321-327. (https://doi.org/10.1038/ nature25480)

Groussin L, Horvath A, Jullian E, Boikos S, Rene-Corail F, Lefebvre H, Cephise-Velayoudom FL, Vantyghem MC, Chanson P, ConteDevolx B, et al. 2006 A PRKAR1A mutation associated with primary pigmented nodular adrenocortical disease in 12 kindreds. Journal of Clinical Endocrinology and Metabolism 91 1943-1949. (https://doi. org/10.1210/jc.2005-2708)

Guo X, Chen H, Fu H \& Wu H 2017 Hereditary leiomyomatosis and renal cell carcinoma syndrome combined with adrenocortical carcinoma on 18F-FDG PET/CT. Clinical Nuclear Medicine $\mathbf{4 2}$ 692-694. (https://doi.org/10.1097/RLU.0000000000001760)

Haller F, Moskalev EA, Faucz FR, Barthelmess S, Wiemann S, Bieg M, Assie G, Bertherat J, Schaefer IM, Otto C, et al. 2014 Aberrant DNA hypermethylation of SDHC: a novel mechanism of tumor development in Carney triad. Endocrine-Related Cancer 21 567-577. (https://doi.org/10.1530/ERC-14-0254)

Hannah-Shmouni F, Demidowich AP, Rowell J, Lodish M \& Stratakis CA 2017 Large pituitary gland with an expanding lesion in the context of neurofibromatosis 1. BMJ Case Reports 2017 bcr-2017-222411. (https://doi.org/10.1136/bcr-2017-222411)

Hao HX, Khalimonchuk O, Schraders M, Dephoure N, Bayley JP, Kunst H, Devilee P, Cremers CW, Schiffman JD, Bentz BG, et al. 2009 SDH5, a gene required for flavination of succinate dehydrogenase, is mutated in paraganglioma. Science 325 1139-1142. (https://doi. org/10.1126/science.1175689)

Hayward BE, Barlier A, Korbonits M, Grossman AB, Jacquet P, Enjalbert A \& Bonthron DT 2001 Imprinting of the G(s)alpha gene GNAS1 in the pathogenesis of acromegaly. Journal of Clinical Investigation 107 R31-R36. (https://doi.org/10.1172/JCI11887)

Heravi-Moussavi A, Anglesio MS, Cheng SW, Senz J, Yang W, Prentice L, Fejes AP, Chow C, Tone A, Kalloger SE, et al. 2012 Recurrent somatic
DICER1 mutations in nonepithelial ovarian cancers. New England Journal of Medicine 366 234-242. (https://doi.org/10.1056/ NEJMoa1102903)

Hernandez-Ramirez LC \& Stratakis CA 2018 Genetics of Cushing's syndrome. Endocrinology Metabolism Clinics of North America $\mathbf{4 7}$ 275-297. (https://doi.org/10.1016/j.ecl.2018.02.007)

Hernandez-Ramirez LC, Gabrovska P, Denes J, Stals K, Trivellin G, Tilley D, Ferrau F, Evanson J, Ellard S, Grossman AB, et al. 2015 Landscape of familial isolated and young-onset pituitary adenomas: prospective diagnosis in AIP mutation carriers. Journal of Clinical Endocrinology and Metabolism 100 E1242-E1254. (https://doi. org/10.1210/jc.2015-1869)

Hernandez-Ramirez LC, Gam R, Valdes N, Lodish MB, Pankratz N, Balsalobre A, Gauthier Y, Faucz FR, Trivellin G, Chittiboina P, et al. 2017 Loss-of-function mutations in the CABLES1 gene are a novel cause of Cushing's disease. Endocrine-Related Cancer 24 379-392. (https://doi.org/10.1530/ERC-17-0131)

Hernández-Ramírez LC, Tatsi C, Lodish MB, Faucz FR, Pankratz N, Chittiboina P, Lane J, Kay DM, Valdés N, Dimopoulos A, et al. 2017 Stratakis corticotropinoma as a component of carney complex. Journal of the Endocrine Society 1 918-925. (https://doi.org/10.1210/ js.2017-00231)

Herraiz M, Barbesino G, Faquin W, Chan-Smutko G, Patel D, Shannon KM, Daniels GH \& Chung DC 2007 Prevalence of thyroid cancer in familial adenomatous polyposis syndrome and the role of screening ultrasound examinations. Clinical Gastroenterology and Hepatology 5 367-373. (https://doi.org/10.1016/j.cgh.2006.10.019)

Horner MJ, Ries LAG, Krapcho M, Neyman N, Aminou R, Howlader N, Altekruse SF, Feuer EJ, Huang L, Mariotto A, et al. 2009 SEER Cancer Statistics Review, 1975-2006. Bethesda, MD, USA: National Cancer Institute.

Horvath A, Mericq V \& Stratakis CA 2008 Mutation in PDE8B, a cyclic AMP-specific phosphodiesterase in adrenal hyperplasia. New England Journal of Medicine 358 750-752. (https://doi.org/10.1056/ NEJMc0706182)

Horvath A, Bertherat J, Groussin L, Guillaud-Bataille M, Tsang K, Cazabat L, Libe R, Remmers E, Rene-Corail F, Faucz FR, et al. 2010 Mutations and polymorphisms in the gene encoding regulatory subunit type 1-alpha of protein kinase A (PRKAR1A): an update. Human Mutation 31 369-379. (https://doi.org/10.1002/humu.21178)

Hsiao HP, Kirschner LS, Bourdeau I, Keil MF, Boikos SA, Verma S, Robinson-White AJ, Nesterova M, Lacroix A \& Stratakis CA 2009 Clinical and genetic heterogeneity, overlap with other tumor syndromes, and atypical glucocorticoid hormone secretion in adrenocorticotropin-independent macronodular adrenal hyperplasia compared with other adrenocortical tumors. Journal of Clinical Endocrinology and Metabolism 94 2930-2937. (https://doi. org/10.1210/jc.2009-0516)

Icard P, Goudet P, Charpenay C, Andreassian B, Carnaille B, Chapuis Y, Cougard P, Henry JF \& Proye C 2001 Adrenocortical carcinomas: surgical trends and results of a 253-patient series from the French Association of Endocrine Surgeons study group. World Journal of Surgery 25 891-897. (https://doi.org/10.1007/s00268-001-0047-y)

Igreja S, Chahal HS, Akker SA, Gueorguiev M, Popovic V, Damjanovic S, Burman P, Wass JA, Quinton R, Grossman AB, et al. 2009 Assessment of p27 (cyclin-dependent kinase inhibitor 1B) and aryl hydrocarbon receptor-interacting protein (AIP) genes in multiple endocrine neoplasia (MEN1) syndrome patients without any detectable MEN1 gene mutations. Clinical Endocrinology 70 259-264. (https://doi. org/10.1111/j.1365-2265.2008.03379.x)

Ishikawa Y, Sugano H, Matsumoto T, Furuichi Y, Miller RW \& Goto M 1999 Unusual features of thyroid carcinomas in Japanese patients with Werner syndrome and possible genotype-phenotype relations to cell type and race. Cancer 85 1345-1352. (https://doi.org/10.1002/ (SICI) 1097-0142(19990315)85:6<1345::AID-CNCR18>3.0.CO;2-\#)

Jackson CE, Norum RA, Boyd SB, Talpos GB, Wilson SD, Taggart RT \& Mallette LE 1990 Hereditary hyperparathyroidism and multiple 
ossifying jaw fibromas: a clinically and genetically distinct syndrome. Surgery 108 1006-1012; discussion 1012-1003.

Jackson MA, Rich TA, Hu MI, Perrier ND \& Waguespack SG 1993 CDC73-related disorders. In GeneReviews. Eds MP Adam, HH Ardinger, RA Pagon, SE Wallace, LJH Bean, HC Mefford, K Stephens, A Amemiya \& N Ledbetter. Seattle, WA, USA: University of Washington.

Jasperson KW, Patel SG \& Ahnen DJ 1993 APC-associated polyposis conditions. In GeneReviews. Eds MP Adam, HH Ardinger, RA Pagon, SE Wallace, LJH Bean, K Stephens \& A Amemiya. Seattle, WA, USA: University of Washington.

Jeunemaitre X, Charru A, Pascoe L, Guyene TT, Aupetit-Faisant B, Shackleton CH, Schambelan M, Plouin PF \& Corvol P 1995 Hyperaldosteronism sensitive to dexamethasone with adrenal adenoma. Clinical, biological and genetic study. La Presse Médicale 24 1243-1248.

Kane LA, Leinung MC, Scheithauer BW, Bergstralh EJ, Laws ER Jr, Groover RV, Kovacs K, Horvath E \& Zimmerman D 1994 Pituitary adenomas in childhood and adolescence. Journal of Clinical Endocrinology and Metabolism 79 1135-1140. (https://doi. org/10.1210/jcem.79.4.7525627)

Kasturi K, Fernandes L, Quezado M, Eid M, Marcus L, Chittiboina P, Rappaport M, Stratakis CA, Widemann B \& Lodish M 2017 Cushing disease in a patient with multiple endocrine neoplasia type $2 \mathrm{~B}$. Journal of Clinical and Translational Endocrinology Case Reports 4 1-4. (https://doi.org/10.1016/j.jecr.2017.02.001)

Kawashima ST, Usui T, Sano T, Iogawa H, Hagiwara H, Tamanaha T, Tagami T, Naruse M, Hojo M, Takahashi JA, et al. 2009 P53 gene mutation in an atypical corticotroph adenoma with Cushing's disease. Clinical Endocrinology 70 656-657. (https://doi. org/10.1111/j.1365-2265.2008.03404.x)

Khan NE, Bauer AJ, Doros L, Schultz KA, Decastro RM, Harney LA, Kase RG, Carr AG, Harris AK, Williams GM, et al. 2017a Macrocephaly associated with the DICER1 syndrome. Genetics in Medicine 19 244-248. (https://doi.org/10.1038/gim.2016.83)

Khan NE, Bauer AJ, Schultz KAP, Doros L, Decastro RM, Ling A, Lodish MB, Harney LA, Kase RG, Carr AG, et al. 2017b Quantification of thyroid cancer and multinodular goiter risk in the DICER1 syndrome: a family-based cohort study. Journal of Clinical Endocrinology and Metabolism 102 1614-1622. (https://doi. org/10.1210/jc.2016-2954)

Kim DW, Kim IJ, Kang HC, Park HW, Shin Y, Park JH, Jang SG, Yoo BC, Lee MR, Hong CW, et al. 2005 Mutation spectrum of the APC gene in 83 Korean FAP families. Human Mutation 26 281. (https://doi. org/10.1002/humu.9360)

King KS, Prodanov T, Kantorovich V, Fojo T, Hewitt JK, Zacharin M, Wesley R, Lodish M, Raygada M, Gimenez-Roqueplo AP, et al. 2011 Metastatic pheochromocytoma/paraganglioma related to primary tumor development in childhood or adolescence: significant link to SDHB mutations. Journal of Clinical Oncology 29 4137-4142. (https:// doi.org/10.1200/JCO.2011.34.6353)

Kirschner LS, Carney JA, Pack SD, Taymans SE, Giatzakis C, Cho YS, Cho-Chung YS \& Stratakis CA 2000 Mutations of the gene encoding the protein kinase A type I-alpha regulatory subunit in patients with the Carney complex. Nature Genetics 26 89-92. (https://doi. org/10.1038/79238)

Krol J, Loedige I \& Filipowicz W 2010 The widespread regulation of microRNA biogenesis, function and decay. Nature Reviews Genetics 11 597-610. (https://doi.org/10.1038/nrg2843)

Kutcher MR, Rigby MH, Bullock M, Trites J, Taylor SM \& Hart RD 2013 Hyperparathyroidism-jaw tumor syndrome. Head and Neck $\mathbf{3 5}$ E175-E177. (https://doi.org/10.1002/hed.22918)

Lacroix A, Bourdeau I, Lampron A, Mazzuco TL, Tremblay J \& Hamet P 2010 Aberrant G-protein coupled receptor expression in relation to adrenocortical overfunction. Clinical Endocrinology 73 1-15. (https:// doi.org/10.1111/j.1365-2265.2009.03689.x)
Lafferty AR \& Chrousos GP 1999 Pituitary tumors in children and adolescents. Journal of Clinical Endocrinology and Metabolism $\mathbf{8 4}$ 4317-4323. (https://doi.org/10.1210/jcem.84.12.6215)

Lafferty AR, Torpy DJ, Stowasser M, Taymans SE, Lin JP, Huggard P, Gordon RD \& Stratakis CA 2000 A novel genetic locus for low renin hypertension: familial hyperaldosteronism type II maps to chromosome 7 (7p22). Journal of Medical Genetics 37 831-835. (https://doi.org/10.1136/jmg.37.11.831)

Lakics V, Karran EH \& Boess FG 2010 Quantitative comparison of phosphodiesterase mRNA distribution in human brain and peripheral tissues. Neuropharmacology 59 367-374. (https://doi. org/10.1016/j.neuropharm.2010.05.004)

Lam AK \& Saremi N 2017 Cribriform-morular variant of papillary thyroid carcinoma: a distinctive type of thyroid cancer. EndocrineRelated Cancer 24 R109-R121. (https://doi.org/10.1530/ERC-17-0014)

Landis CA, Masters SB, Spada A, Pace AM, Bourne HR \& Vallar L 1989 GTPase inhibiting mutations activate the alpha chain of Gs and stimulate adenylyl cyclase in human pituitary tumours. Nature $\mathbf{3 4 0}$ 692-696. (https://doi.org/10.1038/340692a0)

Launbjerg K, Bache I, Galanakis M, Bisgaard ML \& Binderup MLM 2017 von Hippel-Lindau development in children and adolescents. American Journal of Medical Genetics Part A 173 2381-2394. (https:// doi.org/10.1002/ajmg.a.38324)

Lauper JM, Krause A, Vaughan TL \& Monnat RJ Jr 2013 Spectrum and risk of neoplasia in Werner syndrome: a systematic review. PLoS ONE 8 e59709. (https://doi.org/10.1371/journal.pone.0059709)

Lecoq AL, Bouligand J, Hage M, Cazabat L, Salenave S, Linglart A, Young J, Guiochon-Mantel A, Chanson P \& Kamenicky P 2016 Very low frequency of germline GPR101 genetic variation and no biallelic defects with AIP in a large cohort of patients with sporadic pituitary adenomas. European Journal of Endocrinology 174 523-530. (https:// doi.org/10.1530/EJE-15-1044)

Lee M \& Pellegata NS 2013 Multiple endocrine neoplasia type 4. Frontiers of Hormone Research 41 63-78. (https://doi. org/10.1159/000345670)

Levy RA, Hui VW, Sood R, Fish S, Markowitz AJ, Wong RJ \& Guillem JG 2014 Cribriform-morular variant of papillary thyroid carcinoma: an indication to screen for occult FAP. Familial Cancer 13 547-551. (https://doi.org/10.1007/s10689-014-9732-5)

Libe R, Horvath A, Vezzosi D, Fratticci A, Coste J, Perlemoine K, Ragazzon B, Guillaud-Bataille M, Groussin L, Clauser E, et al. 2011 Frequent phosphodiesterase 11A gene (PDE11A) defects in patients with Carney complex (CNC) caused by PRKAR1A mutations: PDE11A may contribute to adrenal and testicular tumors in CNC as a modifier of the phenotype. Journal of Clinical Endocrinology and Metabolism 96 E208-E214. (https://doi.org/10.1210/jc.2010-1704)

Lifton RP, Dluhy RG, Powers M, Rich GM, Cook S, Ulick S \& Lalouel JM 1992 A chimaeric 11 beta-hydroxylase/aldosterone synthase gene causes glucocorticoid-remediable aldosteronism and human hypertension. Nature 355 262-265. (https://doi.org/10.1038/355262a0)

Lindholm J, Juul S, Jorgensen JO, Astrup J, Bjerre P, Feldt-Rasmussen U, Hagen C, Jorgensen J, Kosteljanetz M, Kristensen L, et al. 2001 Incidence and late prognosis of Cushing's syndrome: a populationbased study. Journal of Clinical Endocrinology and Metabolism 86 117-123. (https://doi.org/10.1210/jcem.86.1.7093)

Lodish M \& Stratakis CA 2016 A genetic and molecular update on adrenocortical causes of Cushing syndrome. Nature Reviews Endocrinology 12 255-262. (https://doi.org/10.1038/nrendo.2016.24)

Lodish MB, Keil MF \& Stratakis CA 2018 Cushing's syndrome in pediatrics: an update. Endocrinology Metabolism Clinics of North America 47 451-462. (https://doi.org/10.1016/j.ecl.2018.02.008)

Lomte N, Kumar S, Sarathi V, Pandit R, Goroshi M, Jadhav S, Lila AR, Bandgar T \& Shah NS 2017 Genotype phenotype correlation in Asian Indian von Hippel-Lindau (VHL) syndrome patients with pheochromocytoma/paraganglioma. Familial Cancer [epub]. (https:// doi.org/10.1007/s10689-017-0058-y)
(2) 2018 Society for Endocrinology Published by Bioscientifica Ltd. Printed in Great Britain 
Maddock IR, Moran A, Maher ER, Teare MD, Norman A, Payne SJ, Whitehouse R, Dodd C, Lavin M, Hartley N, et al. 1996 A genetic register for von Hippel-Lindau disease. Journal of Medical Genetics 33 120-127. (https://doi.org/10.1136/jmg.33.2.120)

Maher ER, Iselius L, Yates JR, Littler M, Benjamin C, Harris R, Sampson J, Williams A, Ferguson-Smith MA \& Morton N 1991 Von Hippel-Lindau disease: a genetic study. Journal of Medical Genetics 28 443-447. (https://doi.org/10.1136/jmg.28.7.443)

Martin GA, Viskochil D, Bollag G, McCabe PC, Crosier WJ, Haubruck H, Conroy L, Clark R, O'Connell P, Cawthon RM, et al. 1990 The GAPrelated domain of the neurofibromatosis type 1 gene product interacts with ras p21. Cell 63 843-849. (https://doi. org/10.1016/0092-8674(90)90150-D)

Matyakhina L, Freedman RJ, Bourdeau I, Wei MH, Stergiopoulos SG, Chidakel A, Walther M, Abu-Asab M, Tsokos M, Keil M, et al. 2005 Hereditary leiomyomatosis associated with bilateral, massive, macronodular adrenocortical disease and atypical cushing syndrome: a clinical and molecular genetic investigation. Journal of Clinical Endocrinology and Metabolism 90 3773-3779. (https://doi. org/10.1210/jc.2004-2377)

Matyakhina L, Bei TA, McWhinney SR, Pasini B, Cameron S, Gunawan B, Stergiopoulos SG, Boikos S, Muchow M, Dutra A, et al. 2007 Genetics of carney triad: recurrent losses at chromosome 1 but lack of germline mutations in genes associated with paragangliomas and gastrointestinal stromal tumors. Journal of Clinical Endocrinology and Metabolism 92 2938-2943. (https://doi.org/10.1210/jc.2007-0797)

Mindermann T \& Wilson CB 1995 Pediatric pituitary adenomas. Neurosurgery 36 259-268; discussion 269. (https://doi. org/10.1227/00006123-199502000-00004)

Moers AM, Landsvater RM, Schaap C, Jansen-Schillhorn van Veen JM, de Valk IA, Blijham GH, Hoppener JW, Vroom TM, van Amstel HK \& Lips CJ 1996 Familial medullary thyroid carcinoma: not a distinct entity? Genotype-phenotype correlation in a large family. American Journal of Medicine 101 635-641. (https://doi.org/10.1016/S00029343(96)00330-0)

Monticone S, Tetti M, Burrello J, Buffolo F, De Giovanni R, Veglio F, Williams TA \& Mulatero P 2017 Familial hyperaldosteronism type III. Journal of Human Hypertension 31 776-781. (https://doi. org/10.1038/jhh.2017.34)

Mussa A, Russo S, De Crescenzo A, Chiesa N, Molinatto C, Selicorni A, Richiardi L, Larizza L, Silengo MC, Riccio A, et al. 2013 Prevalence of Beckwith-Wiedemann syndrome in North West of Italy. American Journal of Medical Genetics Part A 161A 2481-2486. (https://doi. org/10.1002/ajmg.a.36080)

Nagy R, Ganapathi S, Comeras I, Peterson C, Orloff M, Porter K, Eng C, Ringel MD \& Kloos RT 2011 Frequency of germline PTEN mutations in differentiated thyroid cancer. Thyroid 21 505-510. (https://doi. org/10.1089/thy.2010.0365)

Nandagopal R, Vortmeyer A, Oldfield EH, Keil MF \& Stratakis CA 2007 Cushing's syndrome due to a pituitary corticotropinoma in a child with tuberous sclerosis: an association or a coincidence? Clinical Endocrinology 67 639-641. (https://doi. org/10.1111/j.1365-2265.2007.02941.x)

Neumann HP, Bausch B, McWhinney SR, Bender BU, Gimm O, Franke G, Schipper J, Klisch J, Altehoefer C, Zerres K, et al. 2002 Germ-line mutations in nonsyndromic pheochromocytoma. New England Journal of Medicine 346 1459-1466. (https://doi.org/10.1056/NEJMoa020152)

Newey PJ, Nesbit MA, Rimmer AJ, Attar M, Head RT, Christie PT, Gorvin CM, Stechman M, Gregory L, Mihai R, et al. 2012 Whole-exome sequencing studies of nonhereditary (sporadic) parathyroid adenomas. Journal of Clinical Endocrinology and Metabolism 97 E1995-E2005. (https://doi.org/10.1210/jc.2012-2303)

Newson AJ \& Schonstein L 2016 Genomic testing in the paediatric population: ethical considerations in light of recent policy statements. Molecular Diagnosis and Therapy 20 407-414. (https://doi. org/10.1007/s40291-016-0210-7)
Ngan ES, Lang BH, Liu T, Shum CK, So MT, Lau DK, Leon TY, Cherny SS, Tsai SY, Lo CY, et al. 2009 A germline mutation (A339V) in thyroid transcription factor-1 (TITF-1/NKX2.1) in patients with multinodular goiter and papillary thyroid carcinoma. Journal of the National Cancer Institute 101 162-175. (https://doi.org/10.1093/jnci/djn471)

Ngeow J, Mester J, Rybicki LA, Ni Y, Milas M \& Eng C 2011 Incidence and clinical characteristics of thyroid cancer in prospective series of individuals with Cowden and Cowden-like syndrome characterized by germline PTEN, SDH, or KLLN alterations. Journal of Clinical Endocrinology and Metabolism 96 E2063-E2071. (https://doi. org/10.1210/jc.2011-1616)

Nordstrom-O'Brien M, van der Luijt RB, van Rooijen E, van den Ouweland AM, Majoor-Krakauer DF, Lolkema MP, van Brussel A, Voest EE \& Giles RH 2010 Genetic analysis of von Hippel-Lindau disease. Human Mutation 31 521-537. (https://doi.org/10.1002/ humu.21219)

Nose V 2008 Familial non-medullary thyroid carcinoma: an update. Endocrine Pathology 19 226-240. (https://doi.org/10.1007/s12022-0089045-z)

Oberg JA, Glade Bender JL, Sulis ML, Pendrick D, Sireci AN, Hsiao SJ, Turk AT, Dela Cruz FS, Hibshoosh H, Remotti H, et al. 2016 Implementation of next generation sequencing into pediatric hematology-oncology practice: moving beyond actionable alterations. Genome Medicine 8 133. (https://doi.org/10.1186/s13073-016-0389-6)

Ong KR, Woodward ER, Killick P, Lim C, Macdonald F \& Maher ER 2007 Genotype-phenotype correlations in von Hippel-Lindau disease. Human Mutation 28 143-149. (https://doi.org/10.1002/humu.20385)

Pamporaki C, Hamplova B, Peitzsch M, Prejbisz A, Beuschlein F, Timmers H, Fassnacht M, Klink B, Lodish M, Stratakis CA, et al. 2017 Characteristics of pediatric vs adult pheochromocytomas and paragangliomas. Journal of Clinical Endocrinology and Metabolism 102 1122-1132. (https://doi.org/10.1210/jc.2016-3829)

Parfitt J, Harris M, Wright JM \& Kalamchi S 2015 Tumor suppressor gene mutation in a patient with a history of hyperparathyroidism-jaw tumor syndrome and healed generalized osteitis fibrosa cystica: a case report and genetic pathophysiology review. Journal of Oral and Maxillofacial Surgery 73 194.e191-194.e199. (https://doi. org/10.1016/j.joms.2014.09.008)

Partington MD, Davis DH, Laws ER Jr \& Scheithauer BW 1994 Pituitary adenomas in childhood and adolescence. Results of transsphenoidal surgery. Journal of Neurosurgery $\mathbf{8 0}$ 209-216. (https://doi.org/10.3171/ jns.1994.80.2.0209)

Pellegata NS, Quintanilla-Martinez L, Siggelkow H, Samson E, Bink K, Hofler H, Fend F, Graw J \& Atkinson MJ 2006 Germ-line mutations in p27Kip1 cause a multiple endocrine neoplasia syndrome in rats and humans. PNAS 103 15558-15563. (https://doi.org/10.1073/ pnas.0603877103)

Pereira JS, da Silva JG, Tomaz RA, Pinto AE, Bugalho MJ, Leite V \& Cavaco BM 2015 Identification of a novel germline FOXE1 variant in patients with familial non-medullary thyroid carcinoma (FNMTC). Endocrine 49 204-214. (https://doi.org/10.1007/s12020014-0470-0)

Pichardo-Lowden AR, Manni A, Saunders BD \& Baker MJ 2011 Familial hyperparathyroidism due to a germline mutation of the CDC73 gene: implications for management and age-appropriate testing of relatives at risk. Endocrine Practice 17 602-609. (https://doi. org/10.4158/EP10337.RA)

Pinto EM, Billerbeck AE, Villares MC, Domenice S, Mendonca BB \& Latronico AC 2004 Founder effect for the highly prevalent R337H mutation of tumor suppressor p53 in Brazilian patients with adrenocortical tumors. Arquivos Brasileiros de Endocrinologia e Metabologia 48 647-650. (https://doi.org/10.1590/S000427302004000500009)

Radin R \& Kempf RA 1995 Carney complex: report of three cases. Radiology 196 383-386. (https://doi.org/10.1148/ radiology.196.2.7617849) 
Reincke M, Sbiera S, Hayakawa A, Theodoropoulou M, Osswald A, Beuschlein F, Meitinger T, Mizuno-Yamasaki E, Kawaguchi K, Saeki Y, et al. 2015 Mutations in the deubiquitinase gene USP8 cause Cushing's disease. Nature Genetics 47 31-38. (https://doi.org/10.1038/ ng.3166)

Ribeiro RC, Sandrini F, Figueiredo B, Zambetti GP, Michalkiewicz E, Lafferty AR, DeLacerda L, Rabin M, Cadwell C, Sampaio G, et al. 2001 An inherited p53 mutation that contributes in a tissue-specific manner to pediatric adrenal cortical carcinoma. PNAS 98 9330-9335. (https://doi.org/10.1073/pnas.161479898)

Richards FM, Payne SJ, Zbar B, Affara NA, Ferguson-Smith MA \& Maher ER 1995 Molecular analysis of de novo germline mutations in the von Hippel-Lindau disease gene. Human Molecular Genetics 4 2139-2143. (https://doi.org/10.1093/hmg/4.11.2139)

Riminucci M, Collins MT, Lala R, Corsi A, Matarazzo P, Gehron Robey P \& Bianco P 2002 An R201H activating mutation of the GNAS1 (Gsalpha) gene in a corticotroph pituitary adenoma. Molecular Pathology 55 58-60. (https://doi.org/10.1136/mp.55.1.58)

Rix M, Hertel NT, Nielsen FC, Jacobsen BB, Hoejberg AS, Brixen K, Hangaard J \& Kroustrup JP 2004 Cushing's disease in childhood as the first manifestation of multiple endocrine neoplasia syndrome type 1. European Journal of Endocrinology 151 709-715. (https://doi. org/10.1530/eje.0.1510709)

Rodriguez-Galindo C, Figueiredo BC, Zambetti GP \& Ribeiro RC 2005 Biology, clinical characteristics, and management of adrenocortical tumors in children. Pediatric Blood and Cancer 45 265-273. (https:// doi.org/10.1002/pbc.20318)

Rosenbaum E, Hosler G, Zahurak M, Cohen Y, Sidransky D \& Westra WH 2005 Mutational activation of BRAF is not a major event in sporadic childhood papillary thyroid carcinoma. Modern Pathology 18 898-902. (https://doi.org/10.1038/modpathol.3800252)

Roskoski R Jr \& Sadeghi-Nejad A 2017 Role of RET protein-tyrosine kinase inhibitors in the treatment RET-driven thyroid and lung cancers. Pharmacological Research 128 1-17. (https://doi. org/10.1016/j.phrs.2017.12.021)

Rostomyan L, Daly AF, Petrossians P, Nachev E, Lila AR, Lecoq AL, Lecumberri B, Trivellin G, Salvatori R, Moraitis AG, et al. 2015 Clinical and genetic characterization of pituitary gigantism: an international collaborative study in 208 patients. Endocrine-Related Cancer 22 745-757. (https://doi.org/10.1530/ERC-15-0320)

Rutter MM, Jha P, Schultz KA, Sheil A, Harris AK, Bauer AJ, Field AL, Geller J \& Hill DA 2016 DICER1 mutations and differentiated thyroid carcinoma: evidence of a direct association. Journal of Clinical Endocrinology and Metabolism 101 1-5. (https://doi. org/10.1210/jc.2015-2169)

Saeger W, Reinhard K \& Reinhard C 1998 Hyperplastic and tumorous lesions of the adrenals in an unselected autopsy series. Endocrine Pathology 9 235-239. (https://doi.org/10.1007/BF02739963)

Sahakitrungruang T, Srichomthong C, Pornkunwilai S, Amornfa J, Shuangshoti S, Kulawonganunchai S, Suphapeetiporn K \& Shotelersuk V 2014 Germline and somatic DICER1 mutations in a pituitary blastoma causing infantile-onset Cushing's disease. Journal of Clinical Endocrinology and Metabolism 99 E1487-E1492. (https:// doi.org/10.1210/jc.2014-1016)

Salenave S, Boyce AM, Collins MT \& Chanson P 2014 Acromegaly and McCune-Albright syndrome. Journal of Clinical Endocrinology and Metabolism 99 1955-1969. (https://doi.org/10.1210/jc.2013-3826)

Sambugaro S, Di Ruvo M, Ambrosio MR, Pellegata NS, Bellio M, Guerra A, Buratto M, Foschini MP, Tagliati F, degli Uberti E, et al. 2015 Early onset acromegaly associated with a novel deletion in CDKN1B 5'UTR region. Endocrine 49 58-64. (https://doi.org/10.1007/ s12020-015-0540-y)

Santoro M, Carlomagno F, Melillo RM \& Fusco A 2004 Dysfunction of the RET receptor in human cancer. Cellular and Molecular Life Sciences 61 2954-2964. (https://doi.org/10.1007/s00018-004-4276-8)
Sassolas G, Hafdi-Nejjari Z, Ferraro A, Decaussin-Petrucci M, Rousset B, Borson-Chazot F, Borbone E, Berger N \& Fusco A 2012 Oncogenic alterations in papillary thyroid cancers of young patients. Thyroid $\mathbf{2 2}$ 17-26. (https://doi.org/10.1089/thy.2011.0215)

Scholl UI, Stolting G, Nelson-Williams C, Vichot AA, Choi M, Loring E Prasad ML, Goh G, Carling T, Juhlin CC, et al. 2015 Recurrent gain of function mutation in calcium channel CACNA1H causes earlyonset hypertension with primary aldosteronism. eLife 4 e06315. (https://doi.org/10.7554/eLife.06315)

Scholl UI, Stolting G, Schewe J, Thiel A, Tan H, Nelson-Williams C, Vichot AA, Jin SC, Loring E, Untiet V, et al. 2018 CLCN2 chloride channel mutations in familial hyperaldosteronism type II. Nature Genetics 50 349-354. (https://doi.org/10.1038/s41588-018-0048-5)

Schultz KAP, Rednam SP, Kamihara J, Doros L, Achatz MI, Wasserman JD, Diller LR, Brugieres L, Druker H, Schneider KA, et al. 2017 PTEN, DICER1, FH, and their associated tumor susceptibility syndromes: clinical features, genetics, and surveillance recommendations in childhood. Clinical Cancer Research 23 e76-e82. (https://doi.org/10.1158/1078-0432.CCR-17-0629)

Shattuck TM, Valimaki S, Obara T, Gaz RD, Clark OH, Shoback D, Wierman ME, Tojo K, Robbins CM, Carpten JD, et al. 2003 Somatic and germ-line mutations of the HRPT2 gene in sporadic parathyroid carcinoma. New England Journal of Medicine 349 1722-1729. (https:// doi.org/10.1056/NEJMoa031237)

Shuman C, Beckwith JB \& Weksberg R 1993 Beckwith-Wiedemann syndrome. In GeneReviews. Eds MP Adam, HH Ardinger, RA Pagon, SE Wallace, LJH Bean, HC Mefford, K Stephens, A Amemiya \& N Ledbetter. Seattle, WA, USA: University of Washington.

Simonds WF, Varghese S, Marx SJ \& Nieman LK 2012 Cushing's syndrome in multiple endocrine neoplasia type 1. Clinical Endocrinology 76 379-386. (https://doi. org/10.1111/j.1365-2265.2011.04220.x)

Smit DL, Mensenkamp AR, Badeloe S, Breuning MH, Simon ME, van Spaendonck KY, Aalfs CM, Post JG, Shanley S, Krapels IP, et al. 2011 Hereditary leiomyomatosis and renal cell cancer in families referred for fumarate hydratase germline mutation analysis. Clinical Genetics 79 49-59. (https://doi. org/10.1111/j.1399-0004.2010.01486.x)

Smith JR, Marqusee E, Webb S, Nose V, Fishman SJ, Shamberger RC, Frates MC \& Huang SA 2011 Thyroid nodules and cancer in children with PTEN hamartoma tumor syndrome. Journal of Clinical Endocrinology and Metabolism 96 34-37. (https://doi.org/10.1210/ jc.2010-1315)

Sorrell AD, Espenschied CR, Culver JO \& Weitzel JN 2013 Tumor protein p53 (TP53) testing and Li-Fraumeni syndrome : current status of clinical applications and future directions. Molecular Diagnosis and Therapy 17 31-47. (https://doi.org/10.1007/s40291-013-0020-0)

Sovinz P, Urban C, Uhrig S, Stepan V, Lackner H, Schwinger W, Benesch M, Moser A, Spuller E \& Speicher MR 2010 Pheochromocytoma in a 2.75-year-old-girl with a germline von Hippel-Lindau mutation Q164R. American Journal of Medical Genetics Part A 152A 1752-1755. (https://doi.org/10.1002/ajmg.a.33407)

Steinhagen E, Guillem JG, Chang G, Salo-Mullen EE, Shia J, Fish S, Stadler ZK \& Markowitz AJ 2012 The prevalence of thyroid cancer and benign thyroid disease in patients with familial adenomatous polyposis may be higher than previously recognized. Clinical Colorectal Cancer 11 304-308. (https://doi.org/10.1016/j. clcc.2012.01.006)

Stratakis CA 2018 An update on Cushing syndrome in pediatrics. Annales d'Endocrinologie 79 125-131. (https://doi.org/10.1016/j. ando.2018.03.010)

Stratakis CA \& Boikos SA 2007 Genetics of adrenal tumors associated with Cushing's syndrome: a new classification for bilateral adrenocortical hyperplasias. Nature Clinical Practice: Endocrinology and Metabolism 3 748-757. (https://doi.org/10.1038/ncpendmet0648)
2018 Society for Endocrinology Published by Bioscientifica Ltd. Printed in Great Britain 
Stratakis CA, Salpea P \& Raygada M 1993 Carney complex. In GeneReviews(R). Eds MP Adam, HH Ardinger, RA Pagon, SE Wallace, LJH Bean, K Stephens \& A Amemiya. Seattle, WA.

Stratakis CA, Courcoutsakis NA, Abati A, Filie A, Doppman JL, Carney JA \& Shawker T 1997 Thyroid gland abnormalities in patients with the syndrome of spotty skin pigmentation, myxomas, endocrine overactivity, and schwannomas (Carney complex). Journal of Clinical Endocrinology and Metabolism 82 2037-2043. (https://doi. org/10.1210/jcem.82.7.4079)

Stratakis CA, Kirschner LS \& Carney JA 2001 Clinical and molecular features of the Carney complex: diagnostic criteria and recommendations for patient evaluation. Journal of Clinical Endocrinology and Metabolism 86 4041-4046. (https://doi. org/10.1210/jcem.86.9.7903)

Stratakis CA, Tichomirowa MA, Boikos S, Azevedo MF, Lodish M, Martari M, Verma S, Daly AF, Raygada M, Keil MF, et al. 2010 The role of germline AIP, MEN1, PRKAR1A, CDKN1B and CDKN2C mutations in causing pituitary adenomas in a large cohort of children, adolescents, and patients with genetic syndromes. Clinical Genetics 78 457-463. (https://doi. org/10.1111/j.1399-0004.2010.01406.x)

Tan TY \& Amor DJ 2006 Tumour surveillance in Beckwith-Wiedemann syndrome and hemihyperplasia: a critical review of the evidence and suggested guidelines for local practice. Journal of Paediatrics and Child Health 42 486-490. (https://doi. org/10.1111/j.1440-1754.2006.00908.x)

Testa JR, Malkin D \& Schiffman JD 2013 Connecting molecular pathways to hereditary cancer risk syndromes. American Society of Clinical Oncology Educational Book 81-90. (https://doi.org/10.1200/ EdBook_AM.2013.33.81)

Thakker RV 2016 Genetics of parathyroid tumours. Journal of Internal Medicine 280 574-583. (https://doi.org/10.1111/joim.12523)

Thakker RV, Newey PJ, Walls GV, Bilezikian J, Dralle H, Ebeling PR, Melmed S, Sakurai A, Tonelli F, Brandi ML, et al. 2012 Clinical practice guidelines for multiple endocrine neoplasia type 1 (MEN1). Journal of Clinical Endocrinology and Metabolism 97 2990-3011. (https://doi.org/10.1210/jc.2012-1230)

Tirosh A, Auerbach A, Bonella B, Zavras PD, Belyavskaya E, Lyssikatos C, Meir K, Weiss R, Daum H, Lodish MB, et al. 2018 Failure to thrive in the context of carney complex. Hormone Research in Paediatrics $\mathbf{8 9}$ 38-46. (https://doi.org/10.1159/000484690)

Tonsgard JH, Yelavarthi KK, Cushner S, Short MP \& Lindgren V 1997 Do NF1 gene deletions result in a characteristic phenotype? American Journal of Medical Genetics 73 80-86. (https://doi.org/10.1002/ (SICI) 1096-8628(19971128)73:1<80::AID-AJMG16>3.0.CO;2-N)

Torpy DJ, Gordon RD, Lin JP, Huggard PR, Taymans SE, Stowasser M, Chrousos GP \& Stratakis CA 1998 Familial hyperaldosteronism type II: description of a large kindred and exclusion of the aldosterone synthase (CYP11B2) gene. Journal of Clinical Endocrinology and Metabolism 83 3214-3218. (https://doi.org/10.1210/jcem.83.9.5086)

Trivellin G, Daly AF, Faucz FR, Yuan B, Rostomyan L, Larco DO, Schernthaner-Reiter MH, Szarek E, Leal LF, Caberg JH, et al. 2014 Gigantism and acromegaly due to Xq26 microduplications and GPR101 mutation. New England Journal of Medicine 371 2363-2374. (https://doi.org/10.1056/NEJMoa1408028)

Uchino S, Ishikawa H, Miyauchi A, Hirokawa M, Noguchi S, Ushiama M, Yoshida T, Michikura M, Sugano K \& Sakai T 2016 Age- and genderspecific risk of thyroid cancer in patients with familial adenomatous polyposis. Journal of Clinical Endocrinology and Metabolism 101 4611-4617. (https://doi.org/10.1210/jc.2016-2043)

Vasef MA, Brynes RK, Sturm M, Bromley C \& Robinson RA 1999 Expression of cyclin D1 in parathyroid carcinomas, adenomas, and hyperplasias: a paraffin immunohistochemical study. Modern Pathology 12 412-416.

Walther MM, Herring J, Enquist E, Keiser HR \& Linehan WM $1999 a$ von Recklinghausen's disease and pheochromocytomas. Journal of Urology 162 1582-1586. (https://doi.org/10.1016/S0022-5347(05)68171-2)

Walther MM, Reiter R, Keiser HR, Choyke PL, Venzon D, Hurley K, Gnarra JR, Reynolds JC, Glenn GM, Zbar B, et al. 1999b Clinical and genetic characterization of pheochromocytoma in von HippelLindau families: comparison with sporadic pheochromocytoma gives insight into natural history of pheochromocytoma. Journal of Urology 162 659-664. (https://doi.org/10.1097/00005392-199909010-00004)

Wasserman JD, Tomlinson GE, Druker H, Kamihara J, Kohlmann WK, Kratz CP, Nathanson KL, Pajtler KW, Parareda A, Rednam SP, et al. 2017 Multiple endocrine neoplasia and hyperparathyroid-jaw tumor syndromes: clinical features, genetics, and surveillance recommendations in childhood. Clinical Cancer Research $\mathbf{2 3}$ e123-e132. (https://doi.org/10.1158/1078-0432.CCR-17-0548)

Wasserman JD, Sabbaghian N, Fahiminiya S, Chami R, Mete O, Acker M, Wu MK, Shlien A, de Kock L \& Foulkes WD 2018 DICER1 mutations are frequent in adolescent-onset papillary thyroid carcinoma. Journal of Clinical Endocrinology and Metabolism 103 2009-2015. (https://doi. org/1.1210/jc.2017-02698)

Watkins-Chow DE \& Camper SA 1998 How many homeobox genes does it take to make a pituitary gland? Trends in Genetics 14 284-290. (https://doi.org/10.1016/S0168-9525(98)01476-0)

Weinstein LS, Shenker A, Gejman PV, Merino MJ, Friedman E \& Spiegel AM 1991 Activating mutations of the stimulatory G protein in the McCune-Albright syndrome. New England Journal of Medicine 325 1688-1695. (https://doi.org/10.1056/NEJM199112123252403)

Wells SA Jr 2018 Advances in the management of MEN2: from improved surgical and medical treatment to novel kinase inhibitors. EndocrineRelated Cancer 25 T1-T13. (https://doi.org/10.1530/ERC-17-0325)

Wells SA Jr \& Santoro M 2009 Targeting the RET pathway in thyroid cancer. Clinical Cancer Research 15 7119-7123. (https://doi. org/10.1158/1078-0432.CCR-08-2742)

Wells SA Jr, Asa SL, Dralle H, Elisei R, Evans DB, Gagel RF, Lee N, Machens A, Moley JF, Pacini F, et al. 2015 Revised American Thyroid Association guidelines for the management of medullary thyroid carcinoma. Thyroid 25 567-610. (https://doi.org/10.1089/thy.2014.0335)

Westin G, Bjorklund P \& Akerstrom G 2009 Molecular genetics of parathyroid disease. World Journal of Surgery 33 2224-2233. (https:// doi.org/10.1007/s00268-009-0022-6)

Xekouki P, Pacak K, Almeida M, Wassif CA, Rustin P, Nesterova M, de la Luz Sierra M, Matro J, Ball E, Azevedo M, et al. 2012 Succinate dehydrogenase (SDH) D subunit (SDHD) inactivation in a growthhormone-producing pituitary tumor: a new association for SDH? Journal of Clinical Endocrinology and Metabolism 97 E357-E366. (https://doi.org/10.1210/jc.2011-1179)

Xu B \& Ghossein R 2016 Genomic landscape of poorly differentiated and anaplastic thyroid carcinoma. Endocrine Pathology 27 205-212. (https://doi.org/10.1007/s12022-016-9445-4)

Yasufuku-Takano J, Takano K, Takei T, Fukumoto S, Teramoto A, Takakura K, Yamashita N \& Fujita T 1999 Heterozygous gsp mutation renders ion channels of human somatotroph adenoma cells unresponsive to growth hormone-releasing hormone. Endocrinology 140 2018-2026. (https://doi.org/10.1210/endo.140.5.6731)

Zbar B, Kishida T, Chen F, Schmidt L, Maher ER, Richards FM, Crossey PA, Webster AR, Affara NA, Ferguson-Smith MA, et al. 1996 Germline mutations in the Von Hippel-Lindau disease (VHL) gene in families from North America, Europe, and Japan. Human Mutation 8 348-357. (https://doi.org/10.1002/(SICI)10981004(1996)8:4<348::AID-HUMU8>3.0.CO;2-3)

Received in final form 29 May 2018

Accepted 31 May 2018 http://ercendocrinology-journals.org https://doi.org/10.1530/ERC-18-0160
2018 Society for Endocrinology Published by Bioscientifica Ltd. Printed in Great Britain 